In: Circulation in the Gulf of Mexico: Observations and Models, W. Sturges and A. Lugo-Fernandez (Eds.), Geophysical Monograph Ser., Vol. 161, pp. 31-56, American Geophysical Union, Washington, D.C., 2005.

\title{
Loop Current, Rings and Related Circulation in the Gulf of Mexico: A Review of Numerical Models and Future Challenges
}

\author{
Oey, L.-Y., T. Ezer, and H.-C. Lee \\ Program in Atmospheric and Oceanic Sciences, Princeton University, Princeton, New Jersey \\ Progress in numerical models of the Loop Current, rings, and related circula- \\ tion during the past three decades is critically reviewed with emphasis on physical \\ phenomena and processes.
}

\section{BACKGROUND: OBSERVATIONS}

The science and art of modeling is deeply rooted in our desire to better describe and understand the world around us: it is imperative that we have some rudimentary knowledge of the system to be modeled. We begin therefore with a summary of observations of the most energetic components of the circulation in the Gulf of Mexico: the Loop Current and Loop Current rings (or eddies; Plate 1). These powerful oceanic features affect, either directly or indirectly through their smaller-scale subsidiaries, just about every aspect of oceanography of the Gulf. One could state that "a necessary condition for a basic model of the Gulf is that it replicates as accurately as possible the observable features of the Loop Current and rings."

The Gulf of Mexico is a semi-enclosed sea that connects in the east to the Atlantic Ocean through the Straits of Florida, and in the south to the Caribbean Sea through the Yucatan Channel (Figure 1). When discussing circulation features and model resolutions, we often find it useful to have some idea of the first-mode (baroclinic) Rossby radius, $\mathrm{R}_{0}$. Calculation based on the GDEM climatology [Teague et al., 1990] gives $\mathrm{R}_{\mathrm{o}} \approx 30 \mathrm{~km}$ in the Gulf and the Cayman Sea (i.e. northwest Caribbean), $\mathrm{R}_{\mathrm{o}} \approx 40 \sim 50 \mathrm{~km}$ in the central and eastern Caribbean Sea, and $\mathrm{R}_{\mathrm{o}} \approx 10 \sim 20 \mathrm{~km}$ over the slope (c.f. Chelton et al. 1998). Though our focus will be on the Gulf, recent studies have indicated that the Gulf

Title

Geophysical Monograph Series

Copyright 2005 by the American Geophysical Union. \#\#.\#\#\#\#/\#\#\#GM\#\# and the Caribbean Sea are dynamically inter-dependent; therefore certain aspects of the circulation in the Caribbean Sea will also be discussed. Currents through the Caribbean Sea, the Gulf of Mexico and the Florida Straits constitute an important component of the subtropical gyre circulation of the North Atlantic Ocean. This fact is vividly presented in Fratantoni's [2001] decadal, quasi-Eulerian mean drifter analysis. The author's Plate 6, for example, shows intense speeds in the Caribbean Current $\left(>0.5 \mathrm{~m} \mathrm{~s}^{-1}\right)$ in the southern portion of the Caribbean Sea, the Loop Current and Florida Current (both $>1 \mathrm{~m} \mathrm{~s}^{-1}$ ).

The Loop Current is the dominant feature of the circulation in the eastern Gulf of Mexico and the formation region of the Florida Current-Gulf Stream system. It originates at the Yucatan Channel (where it is called the Yucatan Current) through which approximately 23 27 Sv $\left(1 \mathrm{~Sv}=10^{6} \mathrm{~m}^{3} \mathrm{~s}^{-1}\right)$ transport passes with a large min-max range of 14 36 Sv [Johns et al. 2002; Sheinbaum et al., 2002; Candela et al., 2003]. The Yucatan/Loop Current is a western boundary current with peak speeds of 1.5 to $1.8 \mathrm{~m} \mathrm{~s}^{-1}$ on the western side of the channel near the surface (Pillsbury, [1887] based on direct current measurements, plotted in Figure 5 of Gordon [1967]; Nowlin [1972] based on GEK; Schlitz [1973] and Carder et al. [1977] based on hydrography; and Ochoa et al. [2001] and Sheinbaum et al. [2002] based on ADCPs and hydrography). In the Loop (inside the Gulf) intense speeds reach $1.7 \mathrm{~m} \mathrm{~s}^{-1}$ in in situ measurements [Forristal et al., 1992]. The Loop Current also displays a wide range of vacillations, both in north-south and east-west directions. The Loop episodically sheds warm-core rings [e.g., Cochrane, 1972; Vukovich, 1995] at intervals of approximately 3 to 17 


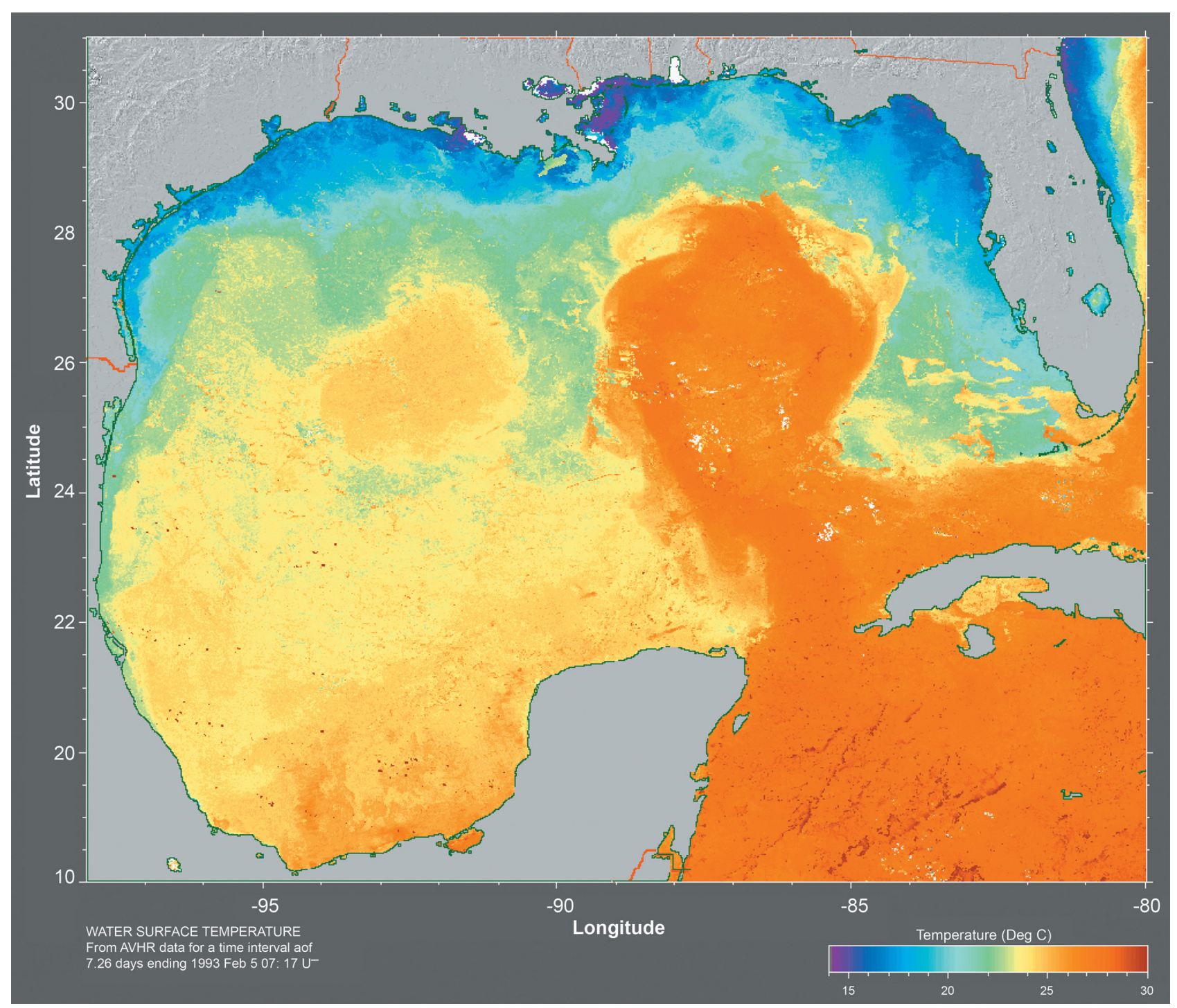

Plate 1. AVHRR (Advanced Very High Resolution Radiometry; http://fermi.jhuapl. edu/avhrr/gm/averages/index.html) seven-day composite sea-surface temperature (SST) for day ending on Feb/05/1998, showing the Loop Current in an extended position into the Gulf, and an old ring further west. Note the appearance of a series of frontal eddies along the outer edges of the Loop Current and the old ring, a cyclone over the east Campeche Bank slope just north of the Yucatan Channel (at $\approx 22.5^{\circ} \mathrm{N}, 87^{\circ} \mathrm{W}$ this cyclone was analyzed in detail by Zavala-Hidalgo et al. 2003), and a Tortugas eddy (cyclone) at $\approx 24^{\circ} \mathrm{N}, 84-85^{\circ} \mathrm{W}$. Approximately two months later the Campeche Bank and Tortugas cyclones appeared to cleave the Loop and a ring was shed. Note also cooler shelf waters and even smaller-scale eddies along the shelf-edge. 


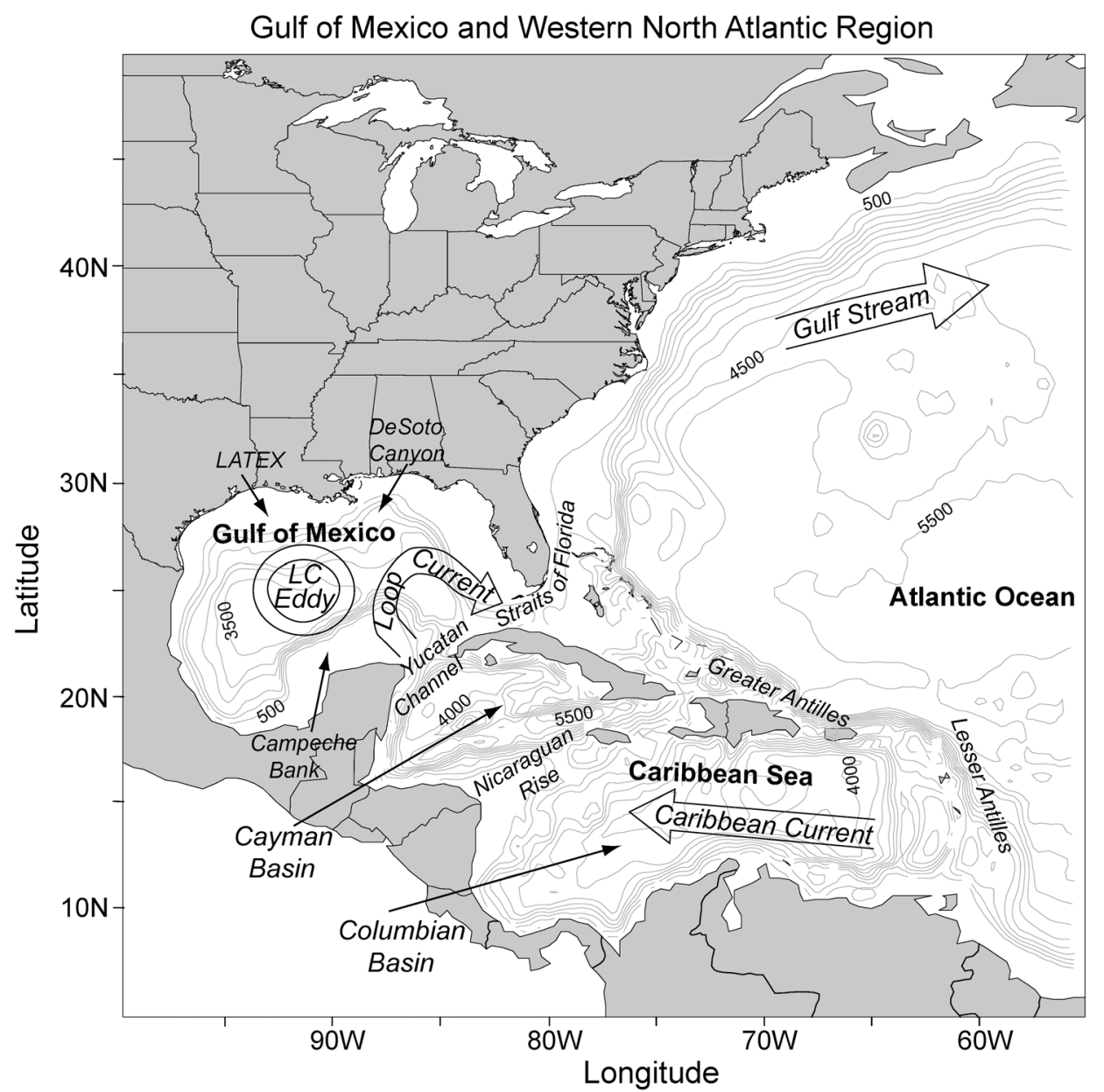

Figure 1. A map for the Gulf of Mexico and the Caribbean Sea with schematic cartoons showing the Caribbean and Loop Currents, Loop Current eddy and the Gulf Stream. The isobaths shown are in meters. This is also the region used by the Princeton models reviewed in the text (e.g. Oey and Lee, 2002).

months [Sturges and Leben, 2000; Leben, this volume]. ${ }^{1}$ These rings have diameters $\approx 200 \sim 300 \mathrm{~km}$, vertical extent $\approx$ $1000 \mathrm{~m}$, swirl speeds $\approx 1.8 \sim 2 \mathrm{~m} \mathrm{~s}^{-1}$; they generally translate westward at 2 5 km day ${ }^{-1}$ and have lifetimes of months to approximately a year [Nowlin, 1972; Elliott, 1982; Vukovich and Crissman, 1986; Cooper et al. 1990; Forristal et al., 1992]. Websites A.3 and A.4 in Appendix 1 provide histori$\mathrm{cal}$ and real-time satellite-derived sea-surface height ( $\mathrm{SSH}$ and other information; please see also the accompanying CD of this book); the reader may consult them for an appreciation of the rich variability of the eddy fields, both inside the Gulf (website A.4) and also in the Caribbean Sea and the Atlantic Ocean (website A.3). ${ }^{2}$
Satellite SSH maps generally resolve scales $\approx 100 \mathrm{~km}$ and larger (though along-track resolution is good at a particular instant, and a composite of several altimeter maps can generally improve resolution [Ducet et al., 2000]). Smaller-scale frontal eddies (or meanders), filamentary structures, and cyclones are often observed around the edges of the Loop Current and rings [Leipper, 1970; Maul, 1977; Vukovich et al., 1979; Huh et al., 1981; Merrell and Morrison, 1981; Brooks and Legeckis, 1982; Paluszkiewicz et al., 1983; Vukovich and Maul, 1985; Vukovich, 1986; Hamilton, 1992; Fratantoni et al., 1998; Hamilton et al., 2003; Zavala-Hidalgo et al., 2003a), as may be seen in satellite AVHRR (Advanced Very High Resolution Radiometry) sea-surface temperature (SST)

\footnotetext{
${ }^{1}$ Leben (this volume) documented two more recent eddies_-eddy Juggernaut (October 1999) and Millenium (April 2001) that have longer shedding period $\approx 18.5$ months.

${ }^{2}$ Appendix 1 contains many useful web-sites, and appendix 2 collects many commonly-used acronyms.
} 
maps (e.g., website A.1; a good one is the seven-day composite on 5 February 1998, shown in Plate 1). These fine-scale features can dominate local circulation, especially in regions removed from direct impacts of the Loop Current and rings (e.g., over the northeastern slope of the Gulf; Hamilton et al. [2000]). Frontal eddies sometimes also appear to originate west of the Loop, propagating clockwise around its northern and eastern edges, and to develop into deeply-penetrating cyclones somewhere along the west Florida continental slope [Vukovich and Maul, 1985]. SST frontal analysis [e.g., Vukovich et al., 1979] indicates amplification time scales of only a few days, as well as backward-wave breaking features. The scales are 50 150 km in diameters and $\sim 1000 \mathrm{~m}$ deep. In the southern Straits of Florida, the cyclones are called Tortugas eddies. Zavala-Hidalgo et al. [2003a] documented cyclones that developed northeast of the Campeche Bank $\left(23.5^{\circ} \mathrm{N}, 86.5^{\circ} \mathrm{W}\right)$. Both the Tortugas eddies and Campeche Bank cyclones appear to be intimately related to the shedding of Loop Current rings [Cochrane, 1972; Fratantoni et al., 1998, who also present an excellent review; Zavala-Hidalgo et al., 2003a; Schmitz, this volume).

The Gulf has a central deep basin (depth $\approx 3500 \mathrm{~m}$ ) of relatively limited extent (about $90^{\circ}-94^{\circ} \mathrm{W}$ and $23^{\circ}-25^{\circ} \mathrm{N}$, Figure 1) surrounded by continental rise, slope and shelves. The Loop Current and rings therefore readily interact with topography; a ring can split and a new ring can interact with an old one. Molinari and Morrison [1988] analyzed data that show effects of the Campeche Bank on Yucatan Current separation and Loop Current penetration. The development of Tortugas eddies is in part a result of the Loop Current being constrained by the west Florida slope [Fratantoni et al., 1998]. Huh et al. [1981] give early examples of Loop Current intrusion into the DeSoto Canyon and Alabama/ Mississippi shelves; more recent work is Hamilton et al. [2000]. Weisberg and He [2003] and Fan et al. [2004] found evidence of west Florida shelf currents being forced by Loop Current "rubbing" against the slope of the south Florida Straits. In the western Gulf, Vidal et al. [1992] describes the collision of a ring with the western slope, during which the ring is split into an anticyclone to the north and a (smaller) cyclone to the south. Biggs et al. [1996] observed an example of Loop Current ring cleaved by a cyclone. Hamilton et al. [2002] found eddies (of both signs) with diameters 40 150 $\mathrm{km}$ over the central Gulf slope. High-resolution AXBT and AXCP also allowed these authors to examine in detail the vertical structures, which showed uplifted $(50 \sim 100 \mathrm{~m})$ iso- therms in the deep $(\sim 1000 \mathrm{~m})$ in the center of the cyclones capped by slight depressions in the upper $200 \mathrm{~m}$, and subsurface maximum velocities with speeds $\approx 0.4 \mathrm{~m} \mathrm{~s}^{-1}$. These Loop Current/eddy interactions with topography strongly affect how energy of the currents is distributed in the water column, and how deep energy propagates along and across isobaths in the form of topographic Rossby waves [Hamilton, 1990; Hamilton and Lugo-Fernandez, 2001].

In summary, the broad range of spatial and temporal scales of the circulation in the Gulf of Mexico presents an enormous challenge for modelers. In the past two to three decades, we have witnessed the development of more and more powerful computers and sophisticated ocean models and analysis techniques. Fueled by these advances and by equally impressive progress on observational data acquisition (from satellite, ADCP, sub-surface floats, surface drifters, etc.; for examples, please see the chapters in this book), the amount of modeling work, presented in papers, reports, and websites, is staggering. It is clearly not possible to review all here. We will restrict our review primarily to models of the Loop Current and rings, which means a model domain that encompasses at least the whole Gulf (with one or two exceptions). In terms of the physical processes we will limit ourselves to subinertial time scales of days and longer (thus excluding tides, internal tides, wind and hurricane-induced high-frequency motions, etc., again with a few exceptions). Perhaps a most glaring omission is near-inertial motions for which the Gulf is well known. These anticyclonic circular motions near the ocean's surface are prevalent over the shelf and shelfbreak and may be forced by near-diurnal variation of the wind (Chen et al. 1996; DiMarco et al. 2000; Simpson et al. 2002). ${ }^{3}$ Discussions of hurricane-induced near-inertial motions (over deep waters) are given by Shay et al. (1998), who also observed significant (short-term) storm effects on an underlying Loop Current eddy. At the subinertial time scales, notably absent from our review is work that describes the (sub-tidal) wind-, buoyancy- (river) and eddy-driven circulation of the continental shelves around the Gulf. ${ }^{4}$ Shelf circulation deserves an entire chapter to itself; the following briefly summarizes some of the more recent papers.

Boicourt et al. [1998] gave a comprehensive review of the shelf circulation in the Gulf. Oey [1995] modeled the wind- and eddy-forced shelf circulation over the LouisianaTexas (LATEX) shelf, and found evidence for eddy-induced shelf edge currents. Hetland et al. [1999] suggested that the impact of Loop Current could spread along the shelf edge,

\footnotetext{
${ }^{3}$ Interestingly, buoy wind data also show large inertial range oscillations near $30^{\circ}$ (Stockwell et al. 2004).

${ }^{4}$ Winds over the Gulf are generally westward, with a predominant anticyclonic curl except for a weak cyclonic curl in a narrow (width $250 \mathrm{~km}$ ) strip along the western coast and a strong cyclonic curl over the Bay of Campeche in the southwestern Gulf [Gutierrez de Velasco and Winant, 1996]. Winds are clearly important over the shelves, but may also affect the large-scale circulation [Sturges, 1993].
} 
thereby inducing a southward jet along the edge of the west Florida shelf. Weisberg's group at USF has described both observations and models of the west Florida shelf [Weisberg and He, 2003; Weisberg et al., this volume]. Muller-Karger [2000] found satellite evidence of northeast Gulf of Mexico (NEGOM) shelf currents driven by both wind and a neighboring Loop Current ring. Ohlmann et al. [2001] used drifters, and pointed out the importance of eddies in forcing the mean flow and in effecting cross-shelf exchanges of water masses. The Texas A\&M group has recently published a number of important papers on the circulation of the LATEX shelf [Li et al., 1997; Cho et al., 1998; Nowlin et al., this volume]. Zavala-Hidalgo et al. [2003b] modeled the western Gulf shelves (west of $89^{\circ} \mathrm{W}$ : LATEX and Mexican shelves) as a contiguous system, carefully computed the shelf transports, found regions of water confluence, and were able to explain transport interrelationship between the different shelves (also Morey et al., this volume). Wang et al. [2003] compared satellite SSH-assimilated model (POM) currents with observations in the DeSoto Canyon $\left(87^{\circ} \mathrm{W}, 29.5^{\circ} \mathrm{N}\right)$ and used the Single Value Decomposition analysis [Bretherton et al., 1992] to study influences on outer-shelf and canyon currents by Loop Current frontal eddies that traveled around the Loop Current. Smith and Jacobs [2005] combined current meter, $\mathrm{ADCP}$, and drifter data in a weighted least square assimilation algorithm to infer the seasonal circulation on both the LATEX and NEGOM shelves.

There are a number of comprehensive reviews of numerical ocean models [Greatbatch and Mellor, 1999; Griffies et al., 2000]. Our focus on a specific region (the Gulf of Mexico) allows an approach that targets physical phenomena and processes. We hope that this review will therefore also be useful to observationalists.

\section{LOOP CURRENT, EDDY SHEDDING, EDDIES \& RELATED CURRENTS}

The first compilation of research work in the Gulf is a book edited by Capurro and J.L. Reid [1972]. Amongst many fine papers (e.g., Nowlin's descriptions of the Gulf's water masses, Cochrane's observations of the Loop Current being cleaved by a cyclone, R.O. Reid's elegant formula of the Loop Current's extension, and Ichiye's laboratory model of the Gulf and the Caribbean), two papers (by Paskausky and Reid, and Wert and Reid) described numerical simulations of the Loop Current and eddy-shedding process. ${ }^{5}$ The authors utilized barotropic and quasi-geostrophic 2-layer models; they were ahead of their time, considering the scarcity of observations and computing resources. Although
Loop Current-like features and eddies were simulated, the experiments were necessarily limited in scope in terms of the parameter space and length of integration they covered. It was not until nearly a decade later that Hurlburt and Thompson [1980] (henceforth HT) developed and extensively tested the first prototype model of the Loop Current and eddy shedding. HT's work is an important yardstick against which many later model experiments and analyses, even those of today, should be measured.

\subsection{Hurlburt and Thompson's Model}

$H T$ experimented with 1-layer barotropic, 1.5-layer reduced-gravity (RG), and 2-layer models of an idealized rectangular Gulf of Mexico basin with inflow (Yucatan Channel; = 20 30 Sv in most experiments) and outflow (Florida Straits) ports. The models are based on the nonlinear primitive equations and resolution is $20 \mathrm{~km} \times 18.75 \mathrm{~km}$. The authors emphasized the importance of integrating the models to a statistical equilibrium so that many eddy-shedding cycles are covered. They introduced the idea of designing first as realistic an experiment as possible (in their case the 2-layer model with topography), then working down to look for the simplest model which could reproduce (essentially) the same results. Both the 2-layer and the1.5 layer model with a steady inflow (and other "reasonable" parameters) produced eddies with diameters $200 \sim 400 \mathrm{~km}$ and shedding periods 250 360 days, while using the same parameters the barotropic flat-bottom case evolved into a steady state. The following summarizes $H T$ 's findings:

1. 1.5-layer model is the simplest relevant model of Loop Current and eddy shedding;

2. Shedding is caused by horizontal shear instability of the internal mode;

3. Shedding occurs despite steady inflow specified at Yucatan Channel;

4. Planetary $\beta$-effect is essential in the Loop Current's penetration into the Gulf (first pointed out by Reid [1972]) and also in eddy-shedding (through westward spreading of the Loop Current and removal of eddies); the penetration time scales dictate shedding time scales;

5. The $f$-plane solution is a steady source-sink flow (no shedding);

6. Nonlinearity is necessary for shedding - the linear solution (when inflow is weak, HT used $0.1 \mathrm{~Sv}$ ) is also a steady source-sink flow;

7. In the 2-layer model, loss of energy due to baroclinic instability to the lower layer results in weaker and

\footnotetext{
${ }^{5}$ The book is a "must-read" for any Gulf aficionado, for its historical value and scientific content.
} 
smaller eddies and in shorter shedding periods (e.g. from 12 months for 1.5-layer model to 8 months for 2-layer with topography, and 5.4 months for 2-layer flat-bottom)

8. Eddy-shedding period is dominated by the natural period ( $\approx 12$ months with steady inflow), though there is also some dependency on time-varying inflow;

9. Eddy-shedding period increases with Reynolds number (please see below); irregular shedding (10 14 months) can occur at a sufficiently high Reynolds number and

10. In the 2-layer model with topography, sufficiently strong (10 Sv) bottom inflow from Yucatan Channel traces a clockwise circulation around the Gulf following the $f / H$ contours; the resulting divergence over the west Florida slope can prevent upper-layer deepening, Loop Current's westward spreading and eddy-shedding. Shedding resumes when the bottom deep inflow weakens.

From the large number of experiments they performed with the 1.5-layer and flat-bottom barotropic models, HT proposed a "Regime Diagram" (their Figure 18) that shows:

E: Eddy-shedding regime for $\mathrm{Re}>\mathrm{Re}_{\mathrm{c}}$ and $\mathrm{R}_{\mathrm{B}}<\mathrm{R}_{\mathrm{Bc}}$; $\underline{W}$ : Steady westward-spreading regime for $\operatorname{Re}<\operatorname{Re}_{c}$ and $\mathrm{R}_{\mathrm{B}}<\mathrm{R}_{\mathrm{Bc}}$; and,

N: Steady source-sink (i.e.,port-to-port) regime for $R_{B}>$ $\mathrm{R}_{\mathrm{Bc}}$, arbitrary $\mathrm{Re}$,

where $R e=v_{\text {in }} L_{h} / A$ is the Reynold's number based on the maximum inflow speed $v_{i n}$, inflow port half-width $\mathrm{L}_{\mathrm{h}}$ and the horizontal eddy viscosity (kinematic) $A$ used in the model, and $\mathrm{R}_{\mathrm{B}}=\mathrm{v}_{\text {in }} /\left(\beta \mathrm{L}_{\mathrm{p}}^{2}\right)$ is the beta Rossby number based on $v_{i n}$, $\beta$, and the half distance, $\mathrm{L}_{\mathrm{p}}$, between the centers of the inflow (Yucatan Channel) and outflow (Florida Straits) ports. The critical Reynold's and beta Rossby numbers, $\mathrm{Re}_{\mathrm{c}}$ and $\mathrm{R}_{\mathrm{B} c}$, are approximately 25 and 2 respectively for the 1.5-layer model. The $\mathrm{R}_{\mathrm{Bc}}$ condition is particularly interesting. That the Loop Current would "short-circuit" from Yucatan-port to Florida-port (i.e., without penetrating into the Gulf and making a loop) when the two ports are close to each other (i.e., $\mathrm{L}_{\mathrm{p}}$ is small) is intuitively clear. However, that this shortcircuiting should occur when $v_{i n}$ is strong is counter-intuitive (c.f. HT's experiments RG40 and RG43, listed in their Table
2). In this case, the tendency for the Loop to spread or bend westward, due to $-\beta v$, is balanced by northward advection of the relative vorticity, $\approx \nu \partial \varsigma / \partial y$, and streamlines tend to curve eastward. ${ }^{6}$ Since in reality (and in all general circulation models or GCMs since $H T$ !) $\beta$ and $\mathrm{L}_{\mathrm{p}}$ are fixed so that $\mathrm{R}_{\mathrm{B}}$ $\propto v_{\text {in }}$, does this mean that (in GCMs and/or the real ocean) a port-to-port mode can occur if surface inflow from the Caribbean increases or if deep inflow increases (HT's finding 10 above), or both? We will see that some GCM runs display this port-to-port mode.

Pichevin and Nof's Analysis. The 1.5-layer model is in general still a very complicated system to solve analytically, but it is much more manageable than the multi-layer or threedimensional GCMs. HT's finding 1 is therefore significant in that an analytical treatment of the 1.5 layer model may provide valuable insights into the dynamics of Loop Current and eddy-shedding. The paper by Pichevin and Nof [1997] (henceforth $P N$; please see also Nof and Pichevin [2001] and Nof et al. [2004]) is an important contribution in this regard. $P N$ analyze the consequences of a northward narrow outflow (i.e., width $\sim$ Rossby radius or less situated next to a southern boundary $)^{7}$ debouching into an open ocean. By integrating the $x$-momentum equation over a rectangular domain just outside the outflow, they show that the integrated momentum exerted on the domain by water exiting the rectangle on the right cannot be balanced in a steady state. This "momentum imbalance paradox," as the authors called it, is resolved if either (timedependent) eddies are allowed to shed to the left $(\beta \neq 0)$ or the outflow grows forever (f-plane; $P N$ 's Figure 6 ). The $\beta$-effect is again a "must" for eddy-shedding. Thus shedding (or growing bulge) in $P N$ is a necessary consequence of the flow's inability to keep the longshore momentum in a steady-state balance. It is important, however, to remember the "narrow outflow" condition implicit in the PN analysis, in which the line integral across the outflow, $\int u v h d x$, is zero, since $\mathrm{u}=0$ there ( $\mathrm{h}$ is the upper-layer depth in their 1.5-layer model). Note that this result does not contradict HT's finding 2. On the other hand, HT's outflow does not grow indefinitely when $\mathrm{f}=$ constant (finding 5; HT's Figure 6). This apparent (but fundamental) discrepancy is puzzling; it may be due to the additional constraint that exists in HT's model: that the port at Florida fixes the magnitude and location of the outflow, i.e., due to the existence of the additional length scale $\mathrm{L}_{\mathrm{p}}$ in $H T^{8}$

\footnotetext{
${ }^{6}$ The assumed steady-state is crucial in HT's argument, which is equivalent to assuming that $(f+\varsigma)=$ constant on geostrophic streamlines. However, see later comparison of HT's and Pichevin and Nof's (1997) work.

${ }^{7}$ Note that the 'narrow-outflow' condition is, strictly speaking, not satisfied in the case of the Yucatan Channel, where $\mathrm{R}_{\mathrm{o}} \approx 30 \mathrm{~km}$ but the channel's width is $\approx 120 \sim 150 \mathrm{~km}$ (Figure 1).

${ }^{8}$ Viscosity $\left(\mathrm{A}\right.$, in $\left.\mathrm{m}^{2} \mathrm{~s}^{-1}\right)$ may also play a role. However, $H T$ 's $\mathrm{A}=10^{3} \mathrm{~m}^{2} \mathrm{~s}^{-1}$ and $P N$ 's $\mathrm{A}=300 \mathrm{~m}^{2} \mathrm{~s}^{-1}$. This difference may be too small to account for the drastic change in the shedding/nonshedding solution.
} 
In summary, $H T$ 's 1.5 -layer model may be simple, yet it captures remarkably well the gross characteristics of Loop Current variability: its extension (growth), shedding of an eddy, and retraction. With reasonable model parameters, the periods are also about right, approximately 12 months. The model also helped to clarify the longstanding misconception that the Loop Current sheds eddies in response to quasiannual variation in inflow through the Yucatan Channel. On the other hand, the real ocean works in a curiously complex manner: the observed shedding periods cover a wide range (approximately 3 to 18.5 months); the Loop Current can extend and retract (scales $\sim$ months and $\mathrm{O}(100 \mathrm{~km})$ ) without necessarily shedding an eddy; an eddy can temporarily detach then reattach to the Loop Current (time scales weeks); frontal meanders, eddies and cyclones can develop and can influence eddy shedding; Yucatan shelf/slope, deeplayer and Caribbean influences may be significant, etc. Later models are developed to capture some of these complications.

Since HT's work, 1.5-layer and 2-layer models have been used by a number of authors. Hurlburt and Thompson [1982] extended their own work to show that Loop Current and eddies force deep modon (anticyclone-cyclone pair with anticyclone leading). The modon in turn can affect the behaviors of the surface eddies. Heburn et al. [1982] studied the instability of the Caribbean Current. Smith and O'Brien [1983] examined eddy interactions with topography. Wallcraft [1986] (please see brief descriptions in Lewis and Kirwan [1987]) extended HT's calculations to high resolutions to simulate small-scale eddies in the Gulf. Arango and Reid [1991] used a generalized 1.5-layer model in isopycnal coordinates to study the shedding process and cyclonic eddies. ${ }^{9}$

\subsection{General Circulation Models with More Realistic Gulf of Mexico Topography}

With the advent of vector-processing machines in the 1980s and early 1990s (CDC Cyber 205, Cray XMP, YMP, C90, etc.), and now of powerful workstations and parallel computers, long-term integrations (to ensure statistical equilibrium) using multi-level and multi-layer primitive equations have become routine.

\subsubsection{Loop Current and Eddies in the Early GCMs. The} first successful GCM computation of the Loop Current and rings was by Sturges et al. [1993], who used MOM [Bryan, 1963; Bryan and Cox, 1967; Cox, 1985; Semtner and Chervin,
1992] at a one-fourth degree horizontal resolution and 12 vertical $z$-levels to examine the characteristics of eddy-shedding. A significant departure from HT is that the model domain $\left(8^{\circ}-36^{\circ} \mathrm{N}, 97^{\circ}-49^{\circ} \mathrm{W}\right)$ includes the Caribbean Sea as well as a portion of the Atlantic Ocean, so that flows in and out of the Gulf through the Yucatan Channel and the Straits of Florida are "free" (i.e., the flow fields there are a solution of the model). The northern boundary $\left(36^{\circ} \mathrm{N}\right)$ is a wall, but the eastern boundary $\left(55^{\circ}-49^{\circ} \mathrm{W}\right)$ is a buffer zone ("pumps and baffles") through which climatological data (including the wind curl-driven integrated transport from east of $49^{\circ} \mathrm{W}$ ) are specified. The modeled flow therefore recirculates. Steady winds were also specified over the modeled domain. These specifications result in $19 \mathrm{~Sv}$ transport into the Gulf through the Yucatan Channel. The horizontal viscosity is $500 \mathrm{~m}^{2}$ $\mathrm{s}^{-1}$, diffusivity is $300 \mathrm{~m}^{2} \mathrm{~s}^{-1}$, and vertical mixing is $10^{-4} \mathrm{~m}^{2}$ $\mathrm{s}^{-1}$. The model was spun up for over 10 years to statistical equilibrium. The model sheds eddies regularly at a period of about 180 days. This is within the observed range, is consistent with HT's finding 7, and suggests a tendency for energy loss to lower layers in a multilevel model. The interesting result (Sturges et al.'s [1993] Figure 7) is that while an eddy is separating, the modeled Loop Current shows recirculating flow inside and even return flow (into the Caribbean) on the Cuban side of the Yucatan Channel (albeit much weaker than the northward jet on the Mexican side). Sturges et al. noted that observations [Nowlin, 1972; Molinari, 1977; Lewis and Kirwan, 1987] show similar recirculation in the Loop Current. The ring's diameter is about $250 \mathrm{~km}$. The ring translates westward at about $4 \mathrm{~km}$ day $^{-1}$ almost on a straight path, and decays at the northwest corner of the Gulf. Peak speeds of about $0.6 \mathrm{~m} \mathrm{~s}^{-1}$ at $130 \mathrm{~m}$ occur in the Loop Current; these speeds decay rapidly in the ring as it moves westward, and drop below $0.2 \mathrm{~m} \mathrm{~s}^{-1}$ at about $92^{\circ} \mathrm{W}$ in the central Gulf. Sturges et al. also described deep eddies, anticyclone (leading) and cyclone pair that follows the surface ring, very similar to the modon found by Hurlburt and Thompson [1982]. These deep eddies are clearly forced by the ring and show remarkably regular periodicity (generation, propagation and decay) phased-locked with the surface ring. One gets the impression that, at one-fourth degree resolution and 12 z-levels, the solution may be too viscous and/or diffusive.

Dietrich and Lin [1994] used a much reduced eddy viscosity $A \approx 1 \sim 10 \mathrm{~m}^{2} \mathrm{~s}^{-1}$ in their Sandia Ocean Modeling System (SOMS), a rigid-lid z-level primitive-equation model on Arakawa C-grid, but with a fourth-order treatment of the Coriolis term [Dietrich, 1993]. The vertical mixing is $10^{-4}$

\footnotetext{
${ }^{9}$ Layer models are now routinely run in multi-layer mode, and are applied not only in the Gulf and the Caribbean Sea (Romanou et al. 2004), but also in other semi-enclosed seas (e.g. Hurlburt et al. 1996; Hurlburt and Hogan, 2000). The U.S. Navy now routinely runs a six-layer global ocean model to help with their forecasting needs (NLOM). See Appendix 1 section D for various model acronyms.
} 
$\mathrm{m}^{2} \mathrm{~s}^{-1}$, the same as that used by Sturges et al. [1993]. The horizontal resolution is $20 \mathrm{~km}$ and there are $16 \mathrm{z}$-levels. The model includes the northwestern portion of the Caribbean Sea (i.e., the Cayman Sea) and thus flow through the Yucatan Channel is also "free." An inflow transport of $30 S v$ is specified across the southeastern open boundary of the model domain in the Caribbean Sea. An outflow is specified at the Straits of Florida. Integration was carried out for four years and results from years 2-4 were shown. The modeled eddies are about $250 \mathrm{~km}$ in diameter, propagate westward at about $3.5 \mathrm{~km}$ day $^{-1}$ and have peak swirl speeds at the first model level $(\mathrm{z}=-22 \mathrm{~m})$ of $0.6 \sim 0.7 \mathrm{~m} \mathrm{~s}^{-1}$. The model appears to be less diffusive than Sturges et al.'s model, but this is difficult to judge from the few snapshots that show similar rapid eddy decays west of about $92^{\circ} \mathrm{W}$. The plots also show a shedding period of about 180 days. When comparing with Sturges et al.'s [1993] results, the period appears to be remarkably insensitive to orders-of-magnitude change in eddy viscosity, contrary to HT's prediction (their finding 9). This may imply the dominance of the baroclinic transfer of energy to the deep, though the short spin-up time in Dietrich and Lin's model may also be a factor. Dietrich et al. [1997] subsequently improved the grid resolution to one-twelfth degree and 20 z-levels using the Arakawa A-grid DieCast model. Although the simulation is still too short ( $\approx 4$ years), the modeled eddies appear to be less dispersive as they traverse westward. The higher resolution also appears to better resolve smaller-scale frontal eddy features at the edges of the Loop Current and rings.

Oey's [1996] terrain-following ocean model (POM) of the Loop Current, rings and their influences on the wind and (river-borne) buoyancy-driven LATEX shelf circulation [Oey, 1995] has a horizontal resolution of $20 \mathrm{~km} \times 20 \mathrm{~km}$ and twenty equally-spaced sigma levels cells in the vertical. ${ }^{10}$ The model domain includes a portion of the northwestern Caribbean Sea (the Cayman Sea, as in Dietrich and Lin, [1994]) and also the Straits of Florida, so that both inflow (Yucatan Channel) and outflow (Straits of Florida) are "free." An inflow transport of $30 \mathrm{~Sv}$ is specified across the southeastern open boundary of the model domain in the Caribbean Sea. Outflow at the northeastern boundary off Florida consists of a combination of transport and radiation conditions [Oey and Chen, 1992]. The model uses Smagorinsky's [1963] shear-dependent formula for the horizontal viscosity and diffusivity, with the constant $\mathrm{C}_{\text {smag }}$. The Mellor and Yamada [1982] level-2.5 turbulence scheme is used for the vertical eddy viscosity and diffusivity. Six runs (each $\approx 10$ years or more) were conducted. Four had $\mathrm{C}_{\text {smag }}$ varied: $0.03,0.05,0.075$ and 0.10 , and two tested the sensitivity of the inflow specifications (not sensitive). These experiments were found to yield irregular eddy shedding, with typical periods 5 15 months (e.g., Oey's [1996] Figure 6). These (periods) should be compared with the 10 14 months obtained from HT's experiment RG8 (HT's Table 2; finding 9) at reduced viscosity $\left(A=300 \mathrm{~m}^{2} \mathrm{~s}^{-1}\right)$, as well as with observed periods 3 17 months [Elliot, 1982; Sturges, 1993; Sturges and Leben, 2000]. The Smagorinsky's formulation typically yielded $A \approx 50 \sim 400 \mathrm{~m}^{2} \mathrm{~s}^{-1}$. Since the specified inflow was steady, Oey [1996] suggested that the shedding irregularity might be due to the generally reduced, and time- and spatiallydependent values of $A$. Other characteristics of Oey's [1996] modeled eddies, such as: diameters $\approx 200 \sim 400 \mathrm{~km}$, westwardpropagation speeds $\approx 3 \sim 5 \mathrm{~km} \mathrm{day}^{-1}$, and peak speeds $\approx 0.6 \sim 0.7$ $\mathrm{m} \mathrm{s}^{-1}$, are similar to those of Sturges et al. [1993] and Dietrich and Lin [1994]. Oey [1996] tracked his eddies only up to $95^{\circ} \mathrm{W}$ prior to their interactions with the western Gulf slope, yielding an "eddy-life" $\approx 6$ months. Oey's [1996] modeled swirl speeds of eddies in the central Gulf $\left(\approx 92^{\circ} \mathrm{W}\right)$ typically are $\approx 0.5 \mathrm{~m} \mathrm{~s}^{-1}$ at $\mathrm{z}=-150 \mathrm{~m}$ (his Figure 18), compared with the $0.2 \mathrm{~m} \mathrm{~s}^{-1}$ at $\mathrm{z}=-130 \mathrm{~m}$ of Sturges et al. [1993] (their Figure 8) and the $0.2 \sim 0.4 \mathrm{~m} \mathrm{~s}^{-1}$ at $\mathrm{z}=-22 \mathrm{~m}$ of Dietrich and Lin [1994] (their Figures 7, 8 and 9) ${ }^{11}$. As mentioned earlier, the eddies in Sturges et al. and Dietrich and Lin tend to weaken considerably west of $92^{\circ} \mathrm{W}$. Oey's [1996] eddies are more similar to Dietrich et al.'s [1997]: they survive past $92^{\circ} \mathrm{W}$ and interact more strongly with the western Gulf slope. Although Oey's eddies appear to be energetic, the modeled eddies and Loop Current are weaker than observed, by as much as $100 \%$ !

\subsubsection{Yucatan (\& Florida Straits) Flow Variability and} Topographic Rossby Waves. Four other results in Oey [1996] seem relevant in light of more recent findings. First, southward deep flow $(z<-750 \mathrm{~m} \text {; transport } \approx 1 \sim 7 \mathrm{~Sv})^{12}$ occurred in the Yucatan Channel each time the model Loop Current extended and shed an eddy; the surface and deep transports are anticorrelated (so that the total inflow is fixed $=30 \mathrm{~Sv}$ ). The southward flows lasted weeks $\sim$ months, appeared to

\footnotetext{
${ }^{10}$ Blumberg and Mellor [1985] used an earlier version of POM to simulate the Gulf's circulation. The coarse grid (1/2 ${ }^{\circ}$ horizontal resolution and 15 vertical sigma-layers) and excessive viscosity and diffusivity (4000 and $2000 \mathrm{~m}^{2} \mathrm{~s}^{-1}$ respectively) probably prevented the modeled Loop Current from shedding rings. The simulation was for one year: the solution was probably dominated by the initial observed climatology.

${ }^{11}$ Dietrich and Lin's [1994] did not include vector scales on their plots.

${ }^{12}$ The usual notation is used such that $x$ and $y$ are west-east and south-north coordinate axes respectively, and $z$ is the vertical coordinate with $z=0$ at the mean sea-level.
} 
precede sheddings, and at times surfaced on the Cuban side of the Yucatan Channel. Oey [1996] noted the potentially interesting relevance of his finding to HT's finding 10: that increased (decreased or even reversed) bottom inflow inhibits (promotes) shedding. He also noted that Maul et al. [1985] observed similar southward (deep) events and the apparent relation of these events to eddy shedding. More recent data and analyses [Bunge et al. 2002; Ezer et al., 2003] support Maul et al.'s and Oey's [1996] findings. Second, Oey noted that these transport fluctuations occurred at shorter periods (weeks $\sim$ months) than eddy-shedding, i.e., not every Loop Current extension (and deep southward flow) resulted in shedding. That the Loop Current has shorter-period fluctuations unrelated to shedding is in contrast to the behaviors of reduced-gravity models, for which a Loop Current extension generally results in shedding ( $H T$ and $P N)$. Third, unlike the Yucatan Channel deep transport, fluctuations in the Straits of Florida show no clear correlation with eddy shedding. Instead, Straits of Florida transports are of even shorter periods (weeks) and energetic near the bottom also. Fourth, flow fluctuations in the western Gulf were found to be correlated with Loop Current variability including eddy-shedding. In particular, for disturbances in the $30 \sim 100$ days' periods, current fluctuations were bottom-intensified (Oey's [1996] Figure 20) and the east-to-west propagation speeds were found to be $\approx 12 \sim 13 \mathrm{~km}$ day $^{-1}$. Oey [1996] cited Hamilton [1990] who attributed the (observed) fluctuations to topographic Rossby waves (TRWs). More recent detailed analyses by Oey and Lee [2002] and Hamilton [2004; this volume] corroborate Hamilton's and Oey's results.

\subsubsection{Non-Shedding Scenarios: An Interesting Difficulty.} The models of Sturges et al. [1993], Dietrich and Lin [1994], Dietrich et al. [1997] and Oey [1996] represent early expansions of HT's work to multi-level with realistic Gulf topography. These multilevel models have a lot in common (all based on the primitive equations, with inflow/outflow and climatological T/S fields, viscosity, etc.), which may explain why the gross behaviors of the modeled Loop Current and eddy-shedding, in terms of the spatial and temporal scales, eddy sizes and propagation paths and speeds, etc. are very similar. With the exception, perhaps, of Dietrich et al.'s [1997] higher-resolution model showing maximum speeds $\approx 2 \mathrm{~m} \mathrm{~s}^{-1}$, all other models' speeds are too weak by as much as $100 \%$ or more in comparison to observations. But they all managed to shed eddies. This may sound trivial until one is reminded of how complex the real-ocean shedding behaviors are, and how incompletely we still actually understand the models' behaviors. It is fitting to close this section on "early GCM's" to mention two recent simulations that do not shed eddies. In a well-designed model of the North Atlantic Ocean (the POP model at $0.1^{\circ} \times 0.1^{\circ}$ resolution and 40 vertical levels), including the Gulf of Mexico and the Caribbean Sea, Smith et al. [2000] found sporadic eddy shedding (roughly once a year) for the first 9 years of integration, as in previous models. For the subsequent 7 years, however, a stationary (nonshedding) Loop Current developed (Smith et al. referred to a similar stationary loop occurring in some of the Community Modeling Effort experiments, [Bryan et al., 1995]). To quote the authors: "The northward flow through Yucatan Strait became shallower and weaker (transport $\sim 17 \mathrm{~Sv}$ ) and the southward recirculation on the eastern side of the strait was enhanced...the vertical shear in the central channel was greatly reduced." The authors attributed the nonshedding behavior to the "decreased vertical shear" consistent with HT's and Oey's [1996] findings. ${ }^{13}$ The implication of an active lower layer invalidates the 1.5-layer model, while enhancement of the southward recirculation on the Cuban side of the channel (c.f. the first of four Oey's [1996] results, described above) may result in nonnegligible cross-channel flows; either or both of these may be sufficient to resolve $P N$ 's "momentum imbalance paradox," making it possible for a nonshedding solution to exist. A similar nonshedding scenario occurs also for the OPA model as reported in Candela et al. [2003]. The ATL6 version of this model encompasses the Atlantic Ocean at one-sixth degree by onesixth degree resolution and 43 vertical levels. To quote the authors, "ATL6 developed a problem in the Gulf of Mexico after the sixth year of simulation (in 1984) that consisted in a blocking of the Loop Current (i.e., it stopped shedding eddies).....an anticyclonic eddy stationed itself to the north of the Yucatan Channel and remained there for the rest of the simulation until the end of 1993." Candela et al. [2003] gave no further details. The nonshedding solution is intriguing: its resolution may go a long way in our understanding of the complex behaviors of the GCMs.

\subsection{More Recent GCM Results}

Later papers that discuss or describe (models of) Loop Current and rings are: Mooers and Maul [1998], Murphy et al. [1999], Welsh and Inoue [2000], Oey and Lee [2002], Ezer et al. [2003], Lee and Mellor [2003], Morey et al. [2003], Zavala-Hidalgo et

\footnotetext{
${ }^{13}$ The weaker transport, $17 \mathrm{~Sv}$, is not likely to be the culprit as HT found shedding with inflow transport as low as $10 \mathrm{~Sv}$ (their experiment RG18), and Sturges et al.'s (1993) transport $=19 S v$ is only tiny bit stronger. The weaker transport also suggests not overly-strong inflow speed, which would actually exclude the port-to-port mode (i.e.,HT's regime $\mathrm{N}$ ) caused by overly large beta Rossby number $R_{B}>R_{B C}$ Also, by weak shears the authors probably meant a more barotropic flow with significant bottom inflow.
} 
al. [2003b], Oey et al. [2003], Candela et al. [2003], Romanou et al. [2004], Oey et al. [2004], Oey [2004a], Cherubin et al. [2005] and Oey et al. [2005]. These later models generally have better resolutions (with one or two exceptions). Apart from Morey et al. [2003] and Zavala-Hidalgo et al. [2003b], who used a domain similar to Dietrich and Lin's [1994] and hence specify essentially the total Yucatan transport (see below), others' domains include the entire Caribbean Sea. Mooers and Maul's POM (at $20 \mathrm{~km}$ resolution and 15 vertical sigma levels; $\mathrm{C}_{\text {smag }}=0.05$ ) domain is similar to that of Sturges et al. [1993], including also the Caribbean Sea. Though the integration was short (1500 days during which 3 eddies were shed), the work suggested a need to treat Caribbean and Loop Currents as an integrated, interconnected system.

2.3.1 Gulf of Mexico \& Caribbean Sea Connection. The Gulf-Caribbean connectivity is explored in Murphy et al. [1999], who experimented with a 5.5-layer reduced gravity as well as a 6-layer global model with realistic bottom topography, both at one-fourth degree resolution; the horizontal viscosity is $300-500 \mathrm{~m}^{2} \mathrm{~s}^{-1}$. The authors found that fragments of the North Brazil Current rings leak in through the Lesser Antilles as potential vorticity perturbations that excite mesoscale eddies in the Caribbean Sea. These eddies amplify and traverse westward, and some manage to squeeze through the Yucatan Channel and affect the timing of Loop Current eddy shedding. The amplification of perturbations and eddyformation in the eastern Caribbean seem to be supported by recent drifter analysis by Richardson [2005], but Simmons and Nof [2002] caution that the one-fouth degree resolution may be too coarse to portray the relevant dynamics correctly. There is not (yet?) direct observational evidence of Caribbean eddies squeezing through the Yucatan Channel (though the Canek moorings across the channel suggest such a possibility; Abascal et al. [2003]), but Murphy et al.'s numerical finding is interesting and potentially significant. Oey et al. [2003] expanded upon Murphy et al.'s ideas, but instead of looking at the progression of individual eddies, they asked if forcing by winds (six-hourly ECMWF was used) and/or by Caribbean eddies (satellite SSH anomaly was used) would affect the statistics of ring-shedding, the periods in particular. Four 16year experiments and one 32-year experiment were conducted using Oey and Lee's [2002] model (POM) in the domain shown in Figure 1. The horizontal grid spacing, $\Delta$, is variable,
$\Delta \approx 25 \mathrm{~km}$ in the eastern Caribbean and decreasing to $\Delta \approx 10$ $\mathrm{km}$ in northwest Caribbean, Yucatan Channel and over the Loop Current $\left(\approx 5 \mathrm{~km}\right.$ in the northern Gulf), and $\mathrm{C}_{\text {smag }}=0.1$. There are 25 sigma levels in the vertical, and steady transports (according to Schmitz [1996]) are specified at the model's open boundary at $55^{\circ} \mathrm{W}$ where climatological $\mathrm{T} / \mathrm{S}$ are also specified. By systematically experimenting with different forcing, Oey et al. [2003] found a dominant shedding period of 9 10 months when there is no wind. ${ }^{14}$ Remote winds over the Atlantic force short-period transport fluctuations in the Yucatan Channel, and the shedding periods then tend to be short (shortest $=3$ months). On the other hand, Caribbean eddies (mostly anticyclones in the model) tend to lengthen the shedding periods (longest $=16$ months). Oey et al. [2003] used the conservation of potential vorticity argument [Reid, 1972; HT] to explain the period-lengthening when Caribbean anticyclones are present: influx of anticyclones into the Gulf would tend to confine the Loop Current close to Yucatan/Florida (i.e., HT's port-to-port mode); shedding is then less likely.

\subsubsection{Deep Processes: Modons, TRW's and Mean Cyclonic} Gyre(s). Welsh and Inoue [2000] improved upon Sturges et al.'s [1993] model with better resolution (one-eighth degree horizontal grid spacing and 15 vertical levels), smaller eddy viscosity and diffusivity (both $=75 \mathrm{~m}^{2} \mathrm{~s}^{-1}$ ) and stronger transport $(28 \mathrm{~Sv})$. The Loop Current rings' characteristics are similar to those found previously. However, the better resolution appears to increase the maximum speeds: approximately 1.3 $\mathrm{m} \mathrm{s}^{-1}$ in the Loop Current and $1 \mathrm{~m} \mathrm{~s}^{-1}$ in the rings. The authors reported that speeds close to $1.75 \mathrm{~m} \mathrm{~s}^{-1}$ were obtained at even higher resolution. Thirteen rings were tracked for the 8 year simulation (after a 12-year spin-up), giving an averaged shedding period $\approx 7.5$ months, slightly longer than Sturges et al.'s. The new insight offered by Welsh and Inoue is their descriptions of the development and westward progression of deep modon: anticyclone-cyclone pair (each $\approx 150 \mathrm{~km}$ in diameter) beneath a modeled ring [c.f. Hurlburt and Thompson, 1982, and Sturges et al., 1993]. The pair forms while the Loop Current ring is being shed. They explained the process in terms of Cushman-Roisin et al.'s [1990] potential-vorticity conservation for a flat-bottom, two-layer ocean. Welsh and Inoue found that the cyclonic component of the modon survives longer (in the western Gulf): this was the first suggestion that deep mean currents in the Gulf might be cyclonic. ${ }^{15}$ Welsh and Inoue's

\footnotetext{
${ }^{14}$ These periods are within the range of HT's "natural" periods of 12 month for the 1.5 -layer model and 8 months for the 2-layer model with bottom topography (c.f. HT's findings 7 and 8 ).

${ }^{15}$ As an observational support for their findings, Welsh and Inoue [2000] quoted Hofmann and Worley's [1986] geostrophic-current estimate at one hydrographic section (section 7 in Hofmann and Worley) to be a cyclone beneath an anticyclone; however, section 7 actually shows the opposite: anticyclone beneath a cyclone. But as pointed out by Hofmann and Worley, the small-scale feature maybe an artifact of their inverse technique.
} 
results also show rich complexities (their Figures 7 and 8), probably because the topography is better resolved than that used in Sturges et al. [1993].

Deep modons with scales and westward propagation speeds similar to those of TRW's (i.e. scales $\approx \mathrm{O}(100 \mathrm{~km})$ and speeds $\approx$ $0.1 \mathrm{~m} \mathrm{~s}^{-1}$ ) can occur in models with a flat bottom [e.g, Hurlburt and Thompson, 1982]. One cannot, therefore, unambiguously interpret the deep motions found by Sturges et al. [1993], Oey [1996] and Welsh and Inoue [2000] as TRWs. On the other hand, observations indicate that TRWs constitute as much as $90 \%$ or more of the deep energy [Hamilton, 1990; Hamilton and Lugo-Fernandez, 2001]. Oey and Lee [2002] examined details of deep energy generated by Loop Current variability and rings in the model described above in conjunction with Oey et al.'s [2003] work. A 10-year experiment was conducted with steady transports and annual-mean climatological T/S specified at the model's open boundary at $55^{\circ} \mathrm{W}$. Through linear-wave and ray-tracing analyses, they show the existence of TRWs at 20 100 day periods. These waves have group velocity (generally westward, $\approx-10 \mathrm{~km} \mathrm{day}^{-1}$ ) and are excited by deep motions caused by meanders (frontal eddies) that swirl around the Loop Current and propagating rings. ${ }^{16}$ The TRWs dominate deep motions along an east-west band as a result of TRW refraction ("confinement") by (i) an escarpment across the central Gulf north of the $3000 \mathrm{~m}$ isobath, and (ii) deep westward current $\left(\approx-0.03 \mathrm{~m} \mathrm{~s}^{-1}\right.$; in region approximately over and north of the $3000 \mathrm{~m}$ isobath) and its cyclonic shear. The authors noted that both their modeled westward group speeds and Hamilton's [1990] from observations were larger in comparison to those derived from the TRW dispersion relation by about 2 to $3 \mathrm{~km} \mathrm{day}^{-1}$. Oey and Lee suggested that the faster westward group velocities in the observations implied the existence of a deep mean westward current $\left(-0.03 \mathrm{~m} \mathrm{~s}^{-1}\right)$ across the central Gulf. Oey and Lee's modeled mean flow is generally cyclonic around the deep Gulf (please see their Figure B.1, which shows mean currents at the model's sigmalevel $20(\approx 200 \mathrm{~m}$ above the bottom in water depths $\approx 2000$ to $3000 \mathrm{~m})$. Oey and Lee's analyses have since been confirmed by Lee and Mellor [2003] using also POM but forced by the NCEP-Eta wind. These latter authors also confirm the cyclonic deep circulation. Of interest is that their Figure 14b appears to show two cyclonic gyres (at $\mathrm{z}=-1500 \mathrm{~m}$ ): one in the eastern Gulf (approximately east of $89^{\circ} \mathrm{W}$, where there is a constriction in isobaths $>3000 \mathrm{~m}$ ) and the other one in the central and western Gulf.

The existence of a deep mean cyclonic gyre (or gyres) found in numerical models has recently been confirmed for subsurface levels deeper than about $1000 \mathrm{~m}$ by DeHaan and Sturges
[2005] based on a careful analysis of historical hydrographic and current-meter data. The authors suggest topographic wave rectification and deep dense inflow from the Caribbean as possible mechanisms. Mizuta and Hogg [2004] show that bottom friction causes the divergence of the vertically integrated Reynolds stress (produced by on-slope propagating TRWs), which in turn induces a mean along-slope flow in the "cyclonic" sense (i.e., shallower water on the right-looking down-current). The bottom boundary layer plays a crucial role as Ekman pumping serves to link the mean current with the Reynolds stresses of the wave field. If we take the typical TRW characteristics in the Gulf, and the bottom slope [e.g., Oey and Lee, 2002], Mizuta and Hogg's analysis then gives a mean cyclonic deep current of about 0.05 to $0.1 \mathrm{~m} \mathrm{~s}^{-1}$. These speeds are comparable with models [Oey and Lee, 2002; Lee and Mellor, 2003], though somewhat stronger than observations (generally $<0.05 \mathrm{~m} \mathrm{~s}^{-1}$; DeHann and Sturges [2005]; Hamilton [2005, submitted to J. Phys. Oceanogr.]). DeHaan and Sturges also have in mind the two-gyre system mentioned above in conjunction with Lee and Mellor's [2003] work, and support their findings by noting that the mean currents computed from PALACE floats at $\mathrm{z}=-900 \mathrm{~m}$ are also generally cyclonic. The PALACE mean currents show a more erratic picture but one can generally discern westward flow in the north central Gulf, southward mean in the west/northwest, a cyclonic gyre in the southwestern Gulf (i.e., the Campeche Bay), and broad eastward flow off the northern Campeche shelf at $90^{\circ} \mathrm{W}$, from $23^{\circ} \mathrm{N} \sim 26^{\circ} \mathrm{N}$, and westward flow further north around $27^{\circ} \mathrm{N}$; the flows are more clearly defined in the west and southwest, but contain smaller-scale features in the central Gulf. (Note that inadequate data prevented DeHaan and Sturges from estimating flows off the northern Campeche shelf). Vazquez de la Cerda et al.'s (this volume) analyses of hydrographic, drifter, floats and satellite data lend further supports that the mean circulation in the Campeche Bay is cyclonic. In light of these observational analyses, future work should extend $O e y$ and Lee's [2002] and Lee and Mellor's [2003] calculations with runs using different forcing, grid-resolution and eddy viscosities, and analyzing dynamics and comparing the results with observations. It is likely that deep flows in the Gulf are TRW and eddy-driven: reminiscence of currents with banded structures seen in idealized studies of geostrophic eddies and turbulence [e.g. ,Vallis and Maltrud, 1993].

\subsubsection{Loop Current and Yucatan Channel Flow Variability.} The potential importance of flow variability through the Yucatan Channel to Loop Current and shedding dynamics was previously mentioned in connection with Maul et al.

\footnotetext{
${ }^{16}$ Oey and Lee [2002] assume a constant buoyancy frequency $(\mathrm{N})$ in their analysis. Reid and Wang [2004] derive a new TRW dispersion relation based on a more realistic exponential (in z) N-profile; the new relation should be tested in future ray-tracing calculations.
} 
[1985]; Oey [1996]; and Oey et al. [2003]. A remarkable data set was more recently obtained in the Yucatan Channel (the Canek Program; Ochoa et al. [2001]; Bunge et al. [2002]; Sheinbaum et al. [2002]; Candela et al. [2003]; Abascal et al. [2003]). The observations consist, among other things, of current-meter and Acoustic Doppler Current Profiler (ADCP) measurements across the channel for 23 months (from August 1999 to June 2001, with a service break in June 2000). The center panel of Figure 2 shows the mean (Figure $2 a$ ) and standard deviation (Figure $2 b$ ) of the along-channel velocity obtained from the Canek observations. The mean is surface intensified near the west (maximum $\approx 1.3 \mathrm{~m} \mathrm{~s}^{-1}$ ). Significant inflow (into the Gulf) extends to $\mathrm{z} \approx-750 \mathrm{~m}$ and occupies nearly the whole width of the channel except for a narrow outflow (i.e. into the Caribbean Sea; $v \approx-0.1 \mathrm{~m} \mathrm{~s}^{-1}$ ) near the surface on the Cuban side of the channel. The deep flow (below $\mathrm{z} \approx-750 \mathrm{~m}$ ) is generally weak, and is directed into the Gulf in the middle, sandwiched between cores of outflows on both sides of the channel. Figure $2 b$ shows that the flow displays considerable variability with a standard deviation $\approx 0.5 \mathrm{~m} \mathrm{~s}^{-1}$ in the main surface core in the west. The standard deviation is as large as (or even larger than) the mean near the surface on the Cuban side and also in the deep. There are also non-negligible cross-channel flows (not shown). Abascal et al. [2003] reported mean cross-channel speeds of $\mathrm{O}\left(0.1 \mathrm{~m} \mathrm{~s}^{-1}\right)$ and standard deviation $\approx 0.15 \mathrm{~m} \mathrm{~s}^{-1}$ near the surface.

Various authors have directly compared their modeled flow field across the Yucatan Channel with Canek observations. Ezer et al. [2003] analyzed in details Oey et al.'s [2003] simulation results. The model set-up is similar to Oey and Lee [2002], described previously, but in addition the model was forced with six-hourly ECMWF wind and monthly climatological surface heat/salt fluxes. The modeled mean and standard deviation are compared with Canek observations in Figure 2 (titled POM), and also in Table 1. The mean shows a strong inflow (maximum $\mathrm{v} \approx 1.5 \mathrm{~m} \mathrm{~s}^{-1}$ ) near the surface in the main western core and deep outflow cores on both sides of the channel $\left(\mathrm{v} \approx-0.05\right.$ to $\left.-0.1 \mathrm{~m} \mathrm{~s}^{-1}\right)$ separated by a weak inflow in the center. These modeled features are similar to those observed. There is also a nearsurface outflow $\left(\mathrm{v} \approx-0.15 \mathrm{~m} \mathrm{~s}^{-1}\right)$ near the Cuban side of the channel though the observed outflow is narrower and weaker $\left(\mathrm{v} \approx-0.1 \mathrm{~m} \mathrm{~s}^{-1}\right)$. The model's main inflow core also extends deeper (the $0.1 \mathrm{~m} \mathrm{~s}^{-1}$ contour is at $\mathrm{z} \approx-900 \mathrm{~m}$ compared to observed $\mathrm{z} \approx-750 \mathrm{~m}$ ). The modeled flow variability is weaker than observation near the surface $(z>-300 \mathrm{~m})$, by more than $50 \%$ in some localized regions. The agreement is good in the deep, where both model and observation show a standard deviation of about $0.05 \mathrm{~m} \mathrm{~s}^{-1} \cdot{ }^{17}$ Ezer et al. [2003] also confirm Oey's [1996] finding of a deep return outflow (into the Caribbean) in connection with eddy-shedding and show, moreover, that the return outflow correlates with changes in the Loop Current extension area in agreement with Bunge et al.'s [2002] observational analysis. Romanou et al. [2004] and Cherubin et al. [2005] found very similar behaviors with the MICOM model.

Candela et al. [2003] use two configurations of the zlevel OPA model, one at one-sixteenth degree resolution - the CLIPPER ATL6 model, and the other at one-twelfth degree resolution - the PAM model (both with 43 z-levels) to compare the flow in the Yucatan channel with Canek observations. The CLIPPER model encompasses the north and south Atlantic oceans $\left(75^{\circ} \mathrm{S}\right.$ to $\left.70^{\circ} \mathrm{N}\right)$, and was spun up for eight years forced by climatological ECMWF air-sea fluxes. It was then continued from 1979 through 1993, forced by daily ECMWF fluxes. Only the first five years of this latter run was analyzed because the model Loop Current stopped shedding eddies after the sixth year (1984 and thereafter; see below). The PAM model covers the north Atlantic Ocean $\left(9^{\circ} \mathrm{N}\right.$ to $\left.70^{\circ} \mathrm{N}\right)$, was spun up for 11 years using ECMWF climatology, and continued another 3 years using daily ECMWF fluxes (1999 to 2001). Results from this latter 3-year run were compared with Canek. Figure 2 and Table 1 show that the modeled Yucatan Channel flows from CLIPPER and PAM share similar characteristics as those from POM, discussed above. The surface shows a main western inflow core and a weak outflow near the Cuban side. The deep outflow cores on both sides of the channel are separated by a weak inflow in the center. The maximum values (both mean and standard deviation) are slightly lower than POM; the exception is the PAM's stronger deep outflow on the eastern side of the channel $(\mathrm{v} \approx$ $-0.1 \mathrm{~m} \mathrm{~s}^{-1}$ at $\mathrm{z} \approx-850 \mathrm{~m}$ ).

The work of Romanou et al. [2004] and Cherubin et al. [2005] represent a first application and validation of MICOM to a relatively small-scale basin with complex topography - the Gulf of Mexico. The model has one-twelfth degree horizontal resolution and 15 vertical layers, and includes the north Atlantic $\left(28^{\circ} \mathrm{S}\right.$ to $\left.65^{\circ} \mathrm{N}\right)$. Monthly mean surface fluxes from COADS were used and the model was run for 20 years; results from the final 5 years were then analyzed. The authors documented the model Loop Current and ring variability. Shedding periods (3 15 months), rings' westward propagation speeds $\left(2 \sim 3 \mathrm{~km} \mathrm{day}^{-1}\right)$ and trajectories, sizes $(300 \sim 400 \mathrm{~km})$, rings' orbital speeds $\left(1.5 \sim 1.9 \mathrm{~m} \mathrm{~s}^{-1}\right)$,

\footnotetext{
${ }^{17}$ Ezer et al. found that the mean and standard deviation of the modeled currents in the channel agree with Maul et al.'s (1985) deep mooring measurement (at $z=-1895 \mathrm{~m}$, near the bottom above the sill).
} 

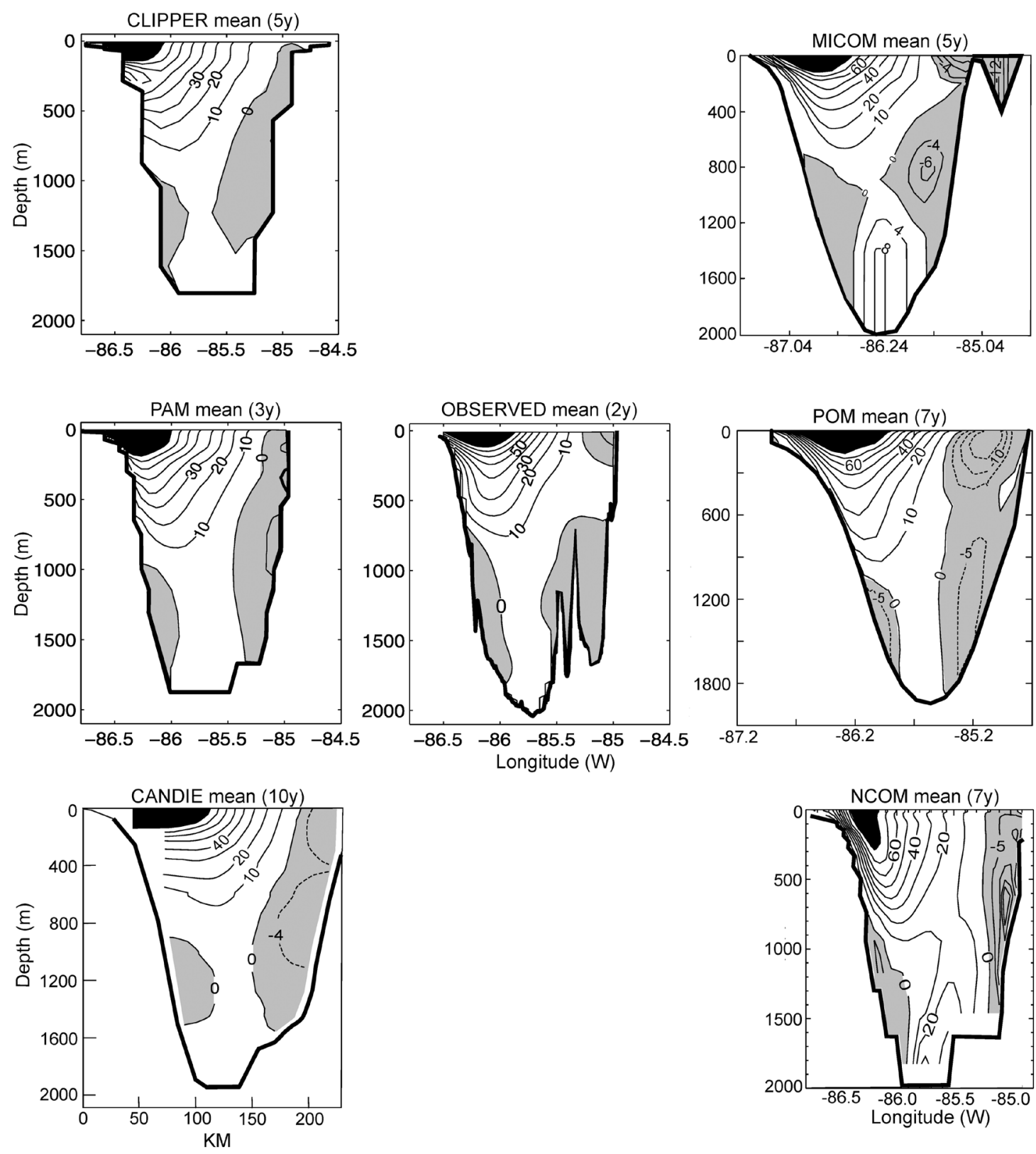

Figure 2a. A comparison between the observed mean flow in the Yucatan Channel (center panel, Candela et al., 2003) and the simulated mean flow in six different models: CLIPPER and PAM are the lower and higher resolution version of OPA (left-upper and left-middle panels, respectively, Candela et al., 2003), CANDIE (left-lower panel, Sheng and Tang, 2003), MICOM (right-upper panel, Romanou, et al., 2004), POM (right-middle panel, Oey et al., 2003, Ezer et al., 2003) and NCOM (right-bottom panel, Morey et al., 2003). Light shaded area represents negative velocity (outflow from the Gulf of Mexico to the Caribbean Sea) and dark area represents large core inflow velocity $\left(v>80 \mathrm{~cm} \mathrm{~s}^{-1}\right)$. The period averaged in each case is indicated. Original figures used different contour intervals and different aspect ratios. The figures were therefore redrawn to the same scale (as it was possible) for ease of comparison, and a common contour interval of $10 \mathrm{~cm} \mathrm{~s}^{-1}$ is used for positive values, but negative contours are kept as in the original figures ( 4 or $5 \mathrm{~cm}$ $\left.s^{-1}\right)$. See Table 1 for more quantitative comparison of velocities and variances. Note the gross similarities between the different models. There are, however, some general differences also, e.g. over the western slope where layer, sigma and sigma-z models (right panels) show outcropping velocity contours (i.e. strong shears) while $z$-level models (left panels) tend to be more homogeneous. 

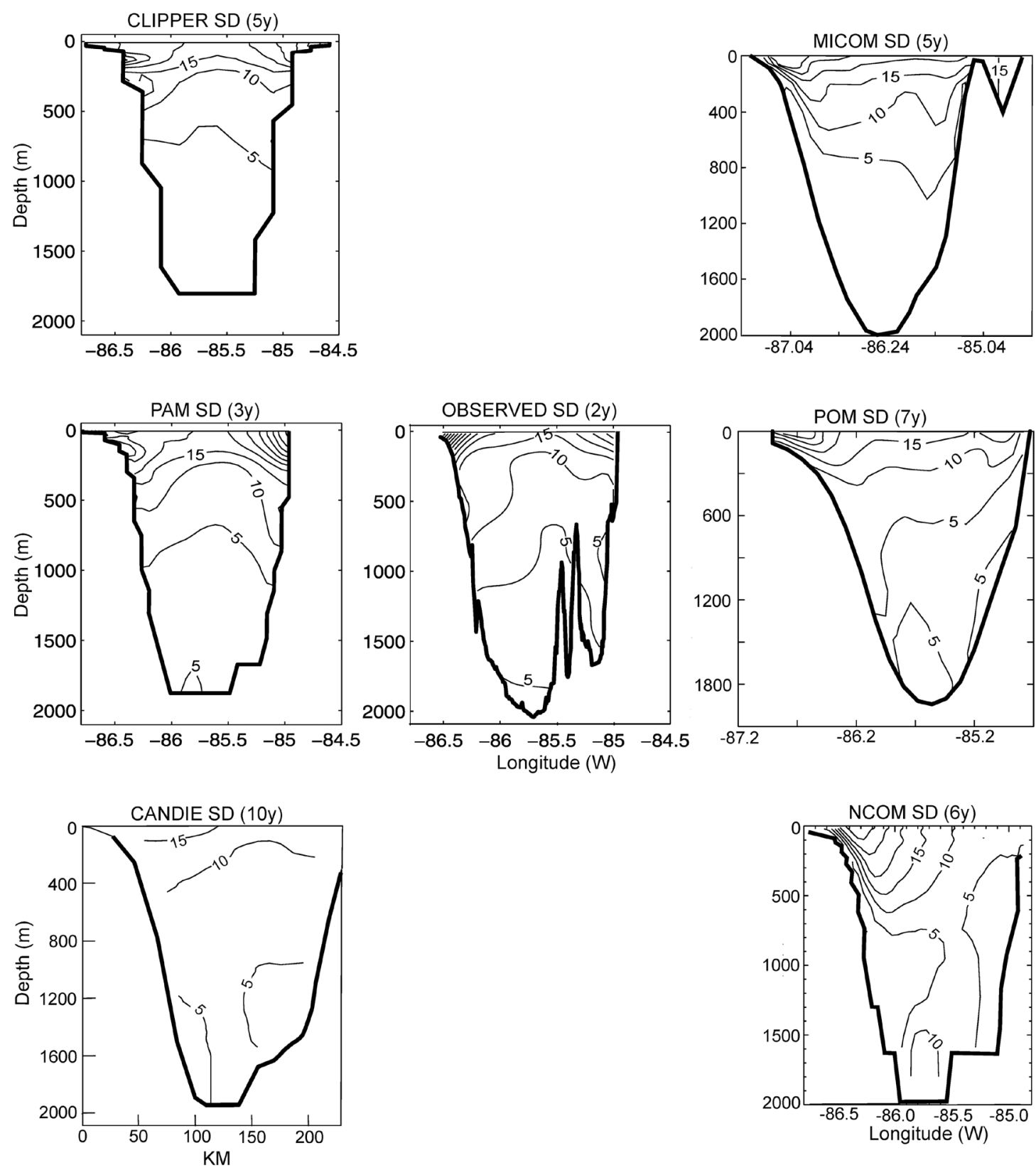

Figure 2b. The standard deviation (SD) of the Yucatan Channel flow from the same models and references indicated in Figure 2a, with two exceptions. The CANDIE and the NCOM original publications did not include plots of SD, and the plots shown here are courtesy of J. Sheng and S. Morey, respectively. All panels were redrawn with the same contour interval of $5 \mathrm{~cm} \mathrm{~s}^{-1}$. The CANDIE calculation here is forced by climatological winds, thus the relatively lower variability in the upper channel. The NCOM calculation is from an experiment with slightly lower channel's transport than that used in Figure 2a. While there are general similarities in the values of SD near the surface, note the differences in the deep variability (below $1200 \mathrm{~m}$ ). The isopycnal model (MICOM, upper right panel) and the coarser resolution z-level model (CLIPPER, upper left panel) have lower variability $\left(\mathrm{SD}<5 \mathrm{~cm} \mathrm{~s}^{-1}\right)$ relative to observations and the other models. 
Table 1. A comparison of mean inflow and outflow velocities and standard deviations at the five observed mean current cores: Yucatan surface and deep, Cuba surface and deep, and central deep, as well as transports and standard deviations from the Canek observations (Ochoa et al. 2001, Sheinbaum et al. 2002 and Candela et al. 2003) and various models at the Yucatan Channel. POM: Oey et al. 2003

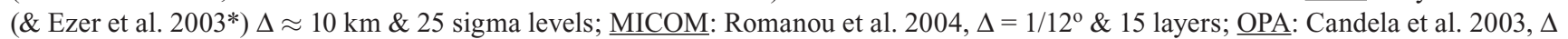

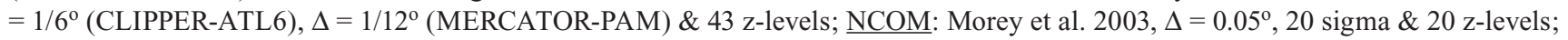
CANDIE: Sheng and Tang 2003, $\Delta \approx 18 \mathrm{~km} \& 31$ z-levels.

\begin{tabular}{|c|c|c|c|c|c|c|c|}
\hline Flow Variables & $\begin{array}{c}\text { CANEK } \\
\text { Observations }\end{array}$ & POM & MICOM & OPA ATL6 & OPA PAM & NCOM & CANDIE \\
\hline $\begin{array}{l}V_{\text {yuc_surf }} \& \\
\text { Std.Dev. }\end{array}$ & $1.2 \pm 0.5$ & $1.5 \pm 0.3$ & $1.2 \pm 0.3$ & $1 \pm 0.25$ & $1.2 \pm 0.25$ & $1 \pm 0.3$ & $1.3 \pm 0.15$ \\
\hline $\begin{array}{l}V_{\text {yuc deep }} \& \\
\text { Std. Dev. }\end{array}$ & $<0, \pm 0.05$ & $-0.05 \pm 0.05$ & $<0 \pm 0.02$ & $<0 \pm 0.05$ & $<0 \pm 0.05$ & $-0.05 \pm 0.05$ & $-0.02 \pm 0.05$ \\
\hline $\begin{array}{c}V_{\text {cuba_surf }} \& \\
\text { Std.Dev. }\end{array}$ & $-0.1 \pm 0.4$ & $-0.2 \pm 0.14$ & $-0.16 \pm 0.2$ & $<0 \pm 0.3$ & $-0.1 \pm 0.45$ & $-0.05 \pm 0.05$ & $-0.04 \pm 0.1$ \\
\hline $\begin{array}{c}V_{\text {cuba_deep }} \& \\
\text { Std.Dev. }\end{array}$ & $<0, \pm 0.05$ & $-0.05 \pm 0.07$ & $-.06 \pm 0.04$ & $<0 \pm 0.05$ & $-0.1 \pm 0.05$ & $-0.2 \pm 0.05$ & $-0.04 \pm 0.05$ \\
\hline $\begin{array}{c}V_{\text {center_deep }} \& \\
\text { Std.Dev. }\end{array}$ & $>0, \pm 0.05$ & $>0, \pm 0.06$ & $0.08 \pm 0.03$ & $>0, \pm 0.05$ & $>0, \pm 0.05$ & $0.2 \pm 0.1$ & $>0 \pm 0.05$ \\
\hline $\begin{array}{l}\text { Transport \& } \\
\text { Std.Dev. }(S v)\end{array}$ & $23 \sim 25 \pm 3$ & $25 \pm 3 *$ to $27 \pm 4$ & $27 \pm 3$ & $27.5 \pm 4$ & $29 \pm 3$ & 32 specified & 26 specified \\
\hline $\begin{array}{l}\text { Transport } \\
\text { Range }(S v)\end{array}$ & $14 \sim 32$ & $\begin{array}{c}16 \sim 34 * \text { to } \\
15 \sim 36\end{array}$ & $18 \sim 32$ & $13 \sim 37$ & $19 \sim 36$ & Not Reported & Not Reported \\
\hline
\end{tabular}

and life spans $(\approx 10 \sim 17$ months $)$ are reasonable in view of observations. Romanou et al. also examined deep eddies, and confirm Sturges et al.'s [1993] and Welsh and Inoue's [2000] findings that these eddies are spun up by Loop Current's extension and ring-shedding. Figure 2 and Table 1 show that MICOM results in the Yucatan Channel have similar characteristics to those from POM and OPA.

Results from two other models, NCOM and CANDIE, are also included in Figure 2 and Table $1 .{ }^{18}$ Morey et al. [2003] applied the NCOM model developed at the Naval Research Laboratory (Martin [2000]; please see also Ko et al. [2003a,b], and Chapman et al. [2004]) to the Gulf of Mexico to study fresh-water pathways. The model domain is similar to that used by Dietrich and Lin [1994] and Oey [1996]: the Gulf and the northwestern portion of the Caribbean Sea; the horizontal resolution is $0.05^{\circ}$. NCOM evolves from POM with one important modification: its vertical grid is hybrid, sigma (as in POM) above a user-specified depth $(\mathrm{z}=-100$ $\mathrm{m}$ was used by Morey et al. with 20 levels) and z-levels (20 was used by Morey et al.) below that depth. Morey et al.'s application uses monthly climatological surface forcing and river inputs are specified as a source term similar to Oey's
[1996] method. Open boundary conditions are a combination of monthly climatology and radiation, and result in $32 \mathrm{~Sv}$ transport through the Yucatan Channel, somewhat high but not too unrealistic. Two 7-year runs were conducted (with different river inputs) following a 4-year spin-up. Though the focus was on fates of fresh water, the authors did report a mean eddy-shedding period of about 10 months with a wide range $\approx 3$ to 15 months. This may be compared with the 5 15 months found by Oey [1996]. The eddies' sizes and trajectories also appear to be similar to those found above by other models. At the fine resolution of $\Delta=0.05^{\circ}$ (i.e. $\Delta / R_{0}$ $\approx 0.25$ in the Gulf), the model shows well-resolved smallscale frontal eddies and meanders around the edge of a ring (their Figure 4). The velocity profile across the Yucatan Channel also shows features similar to those found in other models and in the Canek observations (Table 1 and Figure 2 ); except for strong deep flows in the center of the channel (up to $\left.0.2 \mathrm{~m} \mathrm{~s}^{-1}\right)$ and also over the eastern portion $(v \approx-0.2$ $\left.m \mathrm{~s}^{-1}\right)$; these strong flows are not seen in other models, nor in the Canek observations. The same model was also used by Zavala-Hidalgo et al. [2003b] to study the western shelf circulation in the Gulf.

\footnotetext{
${ }^{18}$ The standard deviation contours (Figure 2b) were not included in the original papers, and Drs. Sheng (CANDIE) and Morey (NCOM) kindly provided the plots for this review.
} 
Sheng and Tang's [2003] model (CANDIE) is for the western Caribbean Sea $\left(72-90^{\circ} \mathrm{W}\right.$ and $\left.8-24^{\circ} \mathrm{N}\right)$ at $18 \mathrm{~km}$ horizontal resolution and with $31 \mathrm{z}$-levels. CANDIE is the Canadian version of the model of Dietrich et al. [1997] with an interesting new implementation: the so-called semiprognostic method that reduces model drift [Sheng et al., 2001]. Instead of adding relaxation terms to the heat and salt equations as in the more common robust prognostic method [Sarmiento and Bryan, 1982], an adiabatic adjustment is made in the momentum equations by replacing the density in the hydrostatic equation by a weighted linear combination of model and climatological densities. Thus artificial heat/salt sinks and sources are eliminated. Instead some model physics are distorted, e.g., wave speeds are changed and additional JEBAR terms appear. Nonetheless the method appears to be successful and can be applied also for nesting [Sheng and Tang, 2004]. In the Caribbean application along the eastern and northern boundaries, Sheng and Tang [2003] forced the model with the one-third degree Atlantic Ocean model (FLAME; Dengg et al. [1999]), which results in $26 \mathrm{~Sv}$ into the Yucatan Channel. Their mean velocity in the channel is also shown in Figure 2, and pertinent velocity and transport values in Table 1. The results are again similar to those of other models. Note that the Yucatan Channel in CANDIE is close to the northern open boundary of the model (at $24^{\circ} \mathrm{N}$ ), so that flow field in the channel may be overly constrained by the boundary conditions. The CANDIE results suggest that the insensitivity of the mean profiles from different models and the relatively good agreements with observations may in part be due more to the similarities of the observed $\mathrm{T} / \mathrm{S}$ climatology used by these models, rather than to specific model physics.

In summary, Figure 2 and Table 1 show that, with a few exceptions as pointed out above, all six models show remarkably similar means and standard deviations in the Yucatan Channel. The model means in general agree with observations, but the model standard deviations are generally lower, by as much as $50 \%$ near the surface. In the deep levels/layers (below $1200 \mathrm{~m}$ ), the isopycnal model (MICOM) and the coarser resolution z-level model (CLIPPER) have lower variability $\left(\mathrm{SD}<5 \mathrm{~cm} \mathrm{~s}^{-1}\right.$ ) relative to observations and the other models. A more subtle difference between the various models is over the western slope where MICOM, POM and NCOM show outcropping velocity contours indicative of strong shears, which are also observed, while CLIPPER, PAM and CANDIE tend to be more homogeneous there. The vertical coordinates in the former group of models are terrain-following and layer, while in the latter it is z-level. It appears that, in this case, the z-level does not resolve the near-surface shelf and slope regions as well as the terrainfollowing and layer models (c.f. Oey et al. [2004]).
Models and observations also show considerable meandering of the Yucatan/Loop Current in the channel, with time scales from weeks to months and transport range (min to max) of 13 37 Sv (Table 1; for examples please see Abascal et al.'s [2003] eddy-propagation mode, and Ezer et al.'s [2003] Figures 5, 6 and 7). The strong variability are also seen in the cross-channel flows. As mentioned previously, Abascal et al. [2003] reported mean cross-channel speeds of $\mathrm{O}\left(0.1 \mathrm{~m} \mathrm{~s}^{-1}\right)$ and standard deviation $\approx 0.15 \mathrm{~m} \mathrm{~s}^{-1}$ near the surface. The cross-channel currents are clearly time-dependent and not always negligible. This added complexity may resolve PN's paradox (so that their line integral across the channel, $\int u v h d x \neq 0$ ), and may allow for a nonshedding solution, or a solution with prolonged and irregular shedding periods.

Candela et al. [2003] made a detailed comparison of the EOFs of the observed and OPA models, and also compared them with the EOFs computed by Ezer et al. [2003]. The observed EOF mode 1 (31\%) is tri-polar, coherent currents on both sides and opposing currents in the center of the channel, while mode $2(23 \%)$ exhibits a bipolar structure that extends deeper to $\mathrm{z} \approx-1000 \mathrm{~m}$. Abascal et al. [2003] interpreted both modes in terms of passages of eddies (anticyclones and cyclones) or anomalies, through the channel (their Figure 18). These anomalies give rise to meanders of the core current in the channel. On the other hand, OPA models give a bipolar mode $1(60 \%)$ and a tripolar mode $2(20 \%)$. Apart from this mode-switch, modeled and observed EOFs are generally similar, though details differ (e.g., periods are longer in models $\approx 100$ days compared to $\approx 20$-100 days in observations [Abascal et al., 2003], the western core of the modeled tripolar structure is subsurface, etc). Oey et al. [2004] suggest that the mode-switch may be an artifact of the fact that observations over the western slope and outer shelf of the channel were not sufficient to resolve Yucatan/Loop Current frontal meanders. By eliminating the upper-slope and shelf currents in their analysis (of the sigma-level model used in Ezer et al. [2003]), Oey et al. [2004] obtained a tri-polar mode 1 and bipolar mode 2 with energy partitions $35 \%$ and $26 \%$ respectively, in agreements with observations. These "filtered" modes correspond to the "slow" meander modes of Abascal et al. (periods > 50 days), while the upper-slope and shelf modes inherent in Ezer et al.'s analysis represent shelf-edge meanders of the Yucatan Current front in the channel, with periods $<50$ days.

Candela et al. [2003] also compared modeled and observed potential vorticity fluxes through the channel. An interesting and potentially significant hypothesis was advanced [also Candela et al., 2002] that these fluxes and Loop Current variability and eddy-shedding are related. The authors suggested that anticyclonic vorticity flux anomaly 
(VFA) extends the Loop Current into the Gulf of Mexico and cyclonic VFA causes retraction or even shedding. In a re-analysis of the Canek and satellite observations, and from the results of a 15-year numerical simulation of eddy shedding, Oey [2004a] found more complex behaviors. It appears that Loop Current retraction or eddy shedding tends to occur shortly (1 2 months) after the influx of VFA at Yucatan has become anticyclonic, and that these events are sometimes preceded by a prolonged period of influx of cyclonic VFA. A plausible explanation consistent with conservation of potential vorticity is that influx of cyclonic VFA tends to extend the Loop Current into the Gulf, thus making the Current more susceptible to retraction or shedding of an eddy, and influx of anticyclonic VFA may then "trigger" retraction or eddy shedding. However, the Loop Current's behaviors are much more complex than can be prescribed by these simple rules. A much longer observational dataset, coupled with more refined model experiments and sophisticated analyses, is required to further quantify the phenomenon.

A detailed analysis of MICOM simulated flow variability in the Yucatan Channel and Loop Current is given in Cherubin et al. [2005]. In the Yucatan Channel, the authors confirm many of the flow and dynamical features found previously by Ezer et al. [2003] and Romanou et al. [2004]. The authors pointed out the significance of the transport spectral peak at around the 100-day period, and suggested that the 205-day period peak found by Maul et al. (1985) and Ezer et al. [2003; POM] may be a double harmonic. Cherubin et al. noted that 100-days is (almost) exactly the period at which Oey et al. [2003] found the spin-up and shedding of anticyclones southwest of Hispaniola (which Oey et al. called "the Hispaniola eddies") by a localized negative wind stress curl, steady or nonsteady, and it is also consistent with the 50 100-day band found by Carton and Chao [1999] in their model simulation of eddy variability in the Caribbean. In support of their model finding, Oey et al. [2003] also showed that the EOF of satellite SSH anomaly gave the 100 days period. Cherubin et al. suggested that the near 100-day Yucatan transport variability is induced by Caribbean eddies. On the other hand, Oey et al. [2003] attributed the near 100-day peak in their spectrum of the upper $800 \mathrm{~m}$ transport (please see their Figure 8, experiment C) to be due to remote wind-induced transports from the Atlantic Ocean through the Greater Antilles passages; this remote wind-forcing idea was consistent with their EOF analysis of transports through the various passages, as well as with the fact that their experiment with steady wind (for which 100-day period Hispaniola eddies also exist) eliminated short-period shedding $(<6$ months). Both studies (Cherubin et al. [2005] and Oey et al. [2003]) may be consistent, in that eddy-shedding at short periods could respond more to potential vorticity than to transport fluctuations. A more detailed analysis is clearly necessary.

\subsubsection{Loop Current Instability and Eddy-Separation.} Cherubin et al. [2005] found an interesting connection between the process of ring-separation and vortex instability [Flierl, 1988]. The instability results in deep cyclones around the Loop Current. Cyclones around the Loop Current have been observed. [Cochrane 1972; Vukovich et al., 1979; Vukovich and Maul, 1985; Fratantoni et al., 1998]. That cyclones may contribute to ring separation from the Loop Current has been proposed [Cochrane, 1972; Hurlburt, 1986; Zavala-Hidalgo et al., 2003a; Schmitz, this volume]. Figure 3 shows a numerical example obtained from Oey and Lee's [2002] POM run at doubled resolution $(\Delta \approx 2-5 \mathrm{~km})$ that appears to lend further support to the finding of Cherubin et al. [2005]. The top-left panel shows an instant when the Loop Current is about to shed a ring (note the west Florida and [smaller] Campeche Bank cyclones; c.f. Zavala-Hidalgo et al. [2003]), and top-right panel 30 days later when the two cyclones appear to cut into the Loop Current as a ring is shed (this ring drifts westward in subsequent times, not shown). The modeled features are often seen whenever shedding occurs just to the north of the Yucatan Channel. The features are robust and have appeared also in the one-twelfth degree resolution DieCast of Dietrich et al. [1997], their Figure 7, in the 10-km-resolution POM of Ezer et al. [2003], their Figure 5, and in the one-twelfth degree resolution MICOM of Romanou et al. [2004], their Figure 1. The deep circulation (lower panels) shows a modon (anticyclone-cyclone pair) structure especially at the earlier time (lower-left panel) with the cyclonic member dominating. Small-scale structures are pervasive due to topography, and Oey and Lee [2002; e.g., their Figure 18] show that TRWs are produced in the vicinity of the $3000 \mathrm{~m}$ isobath in this region.

2.3.5 Loop Current/Ring-Topography Interaction. In contrast to simulations of Loop Current and eddies, there are no detailed model studies of Loop Current/eddy-topography interaction using realistic Gulf of Mexico bathymetry. ${ }^{19}$ The reason may be because there is comparatively much less observation (such as current measurements: e.g., Hamilton [1992]; Hamilton et al. [2002]) against which modelers can directly check their results, although a number of hydrographic, biological, and satellite studies have provided important insights [Paluszkiewicz et al., 1983; Brooks, 1984; Vidal et al., 1992, 1994; Biggs and Muller-Karger, 1994]. There are, however,

\footnotetext{
${ }^{19}$ While Oey and Lee [2002] used realistic topography to study TRWs, they did not examine the interaction process itself.
} 

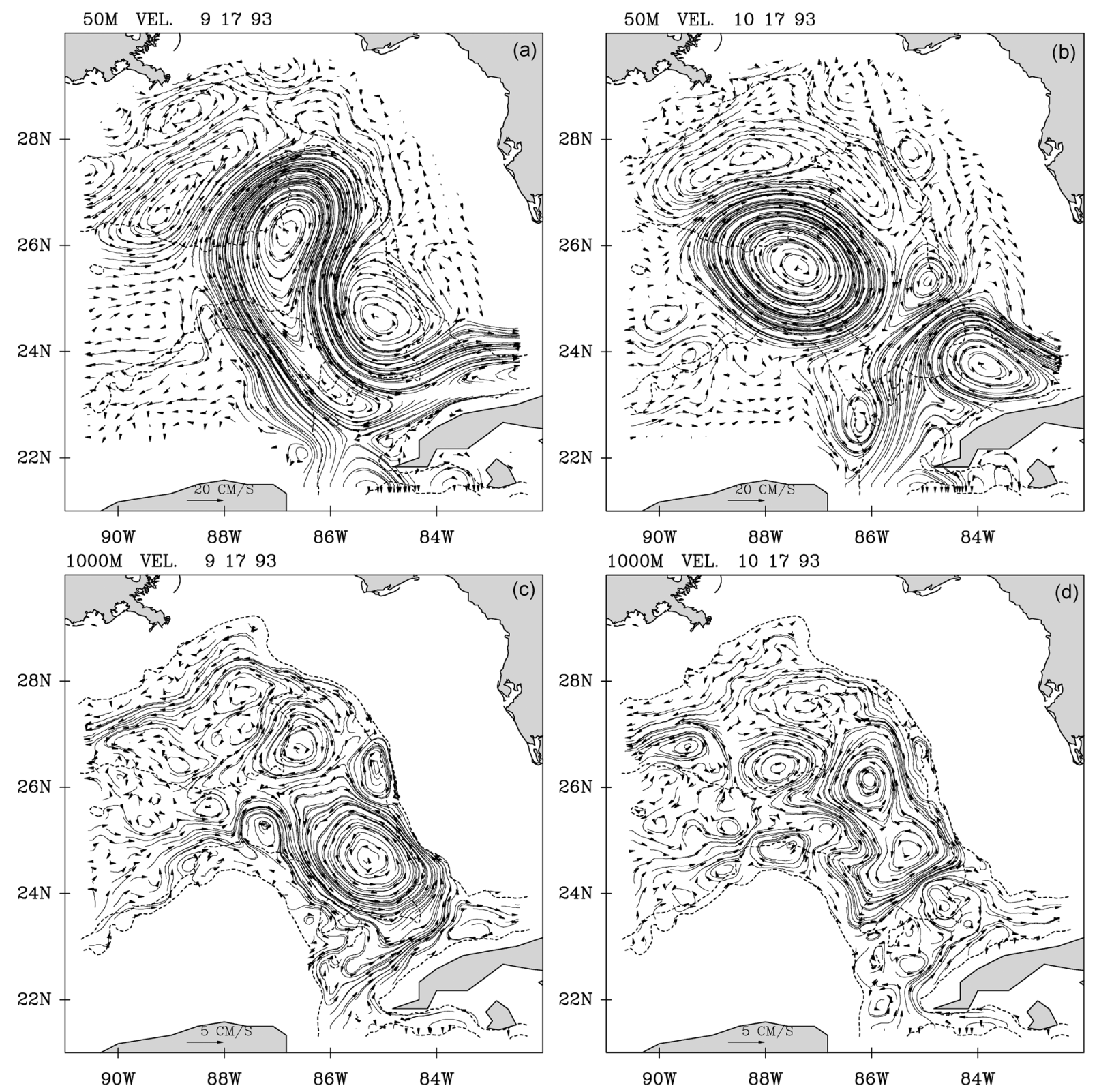

Figure 3. Simulated circulation from a doubled-resolution POM experiment (Oey and Lee, 2002) showing an example when east Campeche Bank and Tortugas cyclones appear to cleave the Loop Current, leading to separation; please see text for more details. The top panels (a and b) are for currents at $z=-50 \mathrm{~m}$ and the lower panels (c and d) for $z=-1000$ $m$. Left panels precede right panels by 30 days. The picture is from the $12^{\text {th }}$ year of a $17-y e a r$ run. Contours show the $1000 \mathrm{~m}$ and $3000 \mathrm{~m}$ isobaths.

important process models with idealized eddies and simple topography. Earliest studies include Smith and O'Brien [1983], Smith [1986] and Smith and Bird [1989]. They showed that $\beta$-dispersion causes asymmetry in the pressure distribution around an eddy leading to nonlinear self-advection [please see also Smith and Reid, 1982; and Matsuura and Yamagata,
1982]. The movement of the eddy then depends on the relative strength and orientation of planetary and topographic $\beta$. The $\beta$-dispersion also tends to obliterate lower-layer features through radiation of topographic Rossby waves, and eddies can quickly ( $\sim 10$ days) evolve to upper-layer features [Grimshaw et al., 1994; LaCasce, 1998]. Other model studies that 
also examine movements of eddies in the presence of slope and/or vertical-walled boundaries include Shi and Nof [1993], Zavala-Sanson et al. [1998], Nof [1999], Sutyrin et al. [2003], and Frolov et al. [2004]. For example, Nof [1999] shows that for a model warm eddy (reduced-gravity type) interacting with a western wall, eddy migration is governed by three processes. The eddy tends to move northward under the image effect, southward due to the $\beta$-induced self-advection, and northward due to the southward expulsion of mass from the eddy (the "rocket" effect).

Subsurface jets. Oey and Zhang [2004] examine a different aspect of a warm eddy impinging upon a continental slope: the generation of parasitic cyclones and jets. This finescale process has apparently not been previously addressed. The study was in part motivated by the curious occurrences of unusually intense subsurface jets, speeds $>0.4 \mathrm{~m} \mathrm{~s}^{-1}$, at z $\approx-300 \mathrm{~m}$ over the slope (water depth $\approx 500 \sim 1000 \mathrm{~m}$ ) documented by the oil industry operating in the northern Gulf of Mexico. The corresponding surface currents during the detection of these jets were weak, so that the energy source did not seem to originate at the surface, at least not directly. The authors found that an extension of Shi and Nof's [1993] reduced-gravity model to a three-dimensional case to be useful. Oey and Zhang [2004] used POM to examine the evolution of a warm ring initially specified over a slope with an adjoining shelf in a periodic channel $(1000 \mathrm{~km} \times 800 \mathrm{~km}$; $\Delta=2.5 \mathrm{~km}$ and 40 equally-spaced sigma cells; maximum slope $|\nabla \mathrm{h}| \approx 3 \times 10^{-2}$, which is typical of the northern Gulf slope). The inviscid response is cyclonic "peeling-off" of the on-slope portion of the warm ring. The cyclone propagates away (to the left looking on-slope) from the warm ring, and is bottom-intensified as well as slope-trapped (cross-slope scale $\approx$ Rossby radius). The viscous response consists of the formation of a bottom boundary layer (BBL) which "lifts" the strong along-slope (leftward) current or jet $(>0.5 \mathrm{~m}$ $\left.\mathrm{s}^{-1}\right)$ away from the bottom. The jet becomes supercritical because of mixing within the BBL and convergence due to downwelling across the slope. Superinertial disturbance in the form of a hydraulic jump or front, with strong upwelling and downwelling cell, and the jet, propagate along the slope as well as off-slope and upward into the water column. The upward propagation is halted at $\mathrm{z} \approx \mathrm{z}_{\text {trap }}$ when mixing smoothes out the "jump" to an along-slope scale $\lambda_{\text {trap }}$ that allows the ambient jet to bend the propagation path horizontal. At this "matured" stage, $\mathrm{z}_{\text {trap }} \approx-250 \mathrm{~m}, \lambda_{\text {trap }} \approx 50$ $\mathrm{km}$, and the jet's cross-slope and vertical scales are $\approx 30 \mathrm{~km}$ and $50 \mathrm{~m}$ respectively. The authors also showed an example under a more realistic setting in the Gulf of Mexico when the (model) Loop Current impinges upon the west Florida slope (they used Oey et al.'s [2003] model at doubled resolution, $\Delta \approx 2$ to $5 \mathrm{~km}$ ).

\section{SUMMARY}

We have made great progress since Hurlburt and Thompson's [1980] pioneering work in modeling the Loop Current and rings in the Gulf of Mexico. The various models all use finite differences and are conveniently distinguished by their vertical grid systems: layer (NLOM, MICOM), zlevel (MOM, DieCast, POP, OPA and CANDIE), sigma-level (POM), and sigma- $z$ hybrid (NCOM); but they also differ, some more than others, in detailed implementations of their horizontal grids, differencing schemes and model physics. Typically, the number of layers or levels is $\mathrm{O}(10)$, though NLOM has also been used in 1.5-layer and 2-layer modes. Most models have horizontal grid sizes $\Delta \approx 10 \sim 25 \mathrm{~km}$, which is probably the coarsest that may be used to resolve rings with diameters $\geq 200 \mathrm{~km}$. However, in terms of the ratio of grid size to (mode-1 baroclinic) Rossby radius, $\Delta / \mathrm{R}_{\mathrm{o}} \approx 0.5 \sim 1$ in the main basins of the Gulf and the Caribbean Sea. This resolution is inadequate to resolve smaller-scale cyclones and frontal eddies. Oey [1998] suggested an empirical criterion that $\Delta / \mathrm{R}_{\mathrm{o}}$ should be less than one-third to resolve mesoscale eddies. The situation is worse at the shelf-edge where $\mathrm{R}_{\mathrm{o}} \approx 10$ $\mathrm{km}$. The doubled-resolution POM, with $\Delta \approx 2 \sim 5 \mathrm{~km}$, and also NCOM at one-twentieth degree resolution look promising, but these models need to be more extensively tested.

Despite the model differences, we have found remarkable similarities in their gross behaviors. Features such as the Loop Current eddy-shedding periods, eddy propagation, paths etc, and others such as the flow profiles in the Yucatan Channel and production of deep cyclones under the Loop Current are similar in the different models. However, there are other details that need to be compared: notably the simulations of TRWs, deep currents, eddy-shelf/slope interaction, as well as frontal eddies and Loop Current eddy-shedding dynamics. The use of different models is a good thing, and inter-comparisons between different models (e.g., DAMEE and DYNAMO experiments; Chassignet et al. [2000]; Meinke et al. [2001]) may be useful. However, there is now a relatively large quantity of good quality, long-term data (one year or more) available in specific regions of the Gulf, some discussed in this volume. In addition to satellite observations and the Canek observations, other long-term data available in specific regions of the Gulf include: the LATEX program, DeSoto Canyon Eddy Intrusion Study ([SAIC and co-investigators; Hamilton et al. [2000]), the Northeastern GOM Chemical Oceanography and Hydrography Program (NEGOM-COH; Jochens et al., 2002), drifters and PALACE floats (Ohlmann and Niiler, 2005, submitted to Progress in Oceanography; DeHaan and Sturges, 2005) and Sigsbee Escarpment measurements [Hamilton et al., 2003]. There are also at least two other field programs presently underway in 
the central and the northwestern Gulf, both being supported by MMS. Intercomparison between different models should therefore be in detail, targeting specific processes, e.g., those mentioned above.

\section{FUTURE CHALLENGES}

Many interesting questions remain with regard to processes that govern Loop Current variability and shedding of rings. First, the existence of a nonshedding solution in some models is a puzzle, and is worth pursuing. Second, Pichevin and Nof's [1997] analysis should be compared against multilevel or multilayer model results for the validity of the various simplifying assumptions made, e.g., the narrow-channel, parallel-outflow assumption; the comparison can lead to extensions of the analytical method. It is also of interest to resolve the discrepancy (on f-plane) between Pichevin and Nof's forever-growing bulge solution and Hurlburt and Thompson's [1980] steady-bulge solution. Though these issues are model-specific, their resolutions may improve our understanding of the observed Loop Current's behaviors. Third, the development of deep cyclones under the Loop Current is of great interest and should be pursued further, especially with regard to their possible upstream (e.g., Yucatan Channel, Campeche Bank cyclones) connection, and their relation to eddy-separation from the Loop [Schmitz, this volume]. It is possible that the majority of the cyclones in the Gulf originate under the Loop Current. Fourth, the potential importance of upstream conditions to Loop Current behaviors should be more thoroughly studied, especially with regard to the interesting Atlantic-CaribbeanGulf connection in terms of the formation and propagation of eddies in the Caribbean and wind-induced transport and (potential) vorticity fluctuations at the Yucatan Channel. Fifth, the Caribbean-Gulf connection, in terms of both the dynamics of eddies "squeezing" into the Gulf and also deep cold inflow, should be carefully examined. Sixth, in addition to Loop Current and eddy-shedding, the cause(s) for deep mean cyclonic gyres in the Gulf could be found by a careful analysis of the numerical model results, as well as designs of some appropriate "process" experiments to isolate forcing. Seventh, the process of ring-slope interaction using realistic topography should be further explored with high-resolution models (with $\Delta / \mathrm{R}_{\mathrm{o}} \approx 1 / 3$ or less). The relaxation of the hydrostatic constraint in some processes that involve smallscale jets and mixing may be necessary. Nonhydrostatic general circulation models have emerged in recent years [e.g., Marshall et al., 1997]. They should be more widely tested; the shelf-edge and slope seem to be an ideal test site. In view of the non-negligible influences of eddies on shelf processes (please see references cited in the "Background" section), the slope interaction study is of significant practical importance especially for regional shelf models that must rely on the Gulf-scale models for their open-boundary conditions.

Improved model processes not only lead to a better understanding of the ocean circulation, they also enhance our skills in describing and hopefully predicting ocean states for practical services that directly impact the aesthetic as well as economic aspects of civilizations. Therefore, in addition to checking and understanding processes, outlined above, models should also be intercompared for their skills in reproducing observed time series. This requires hindcast studies and skill-assessment, a necessary step for achieving more accurate forecast. In the hindcast and skill-assessment studies, one may borrow recent ideas from the meteorologists Tselioudis et al. [2004], and use the web for assembling data (for model initializations, boundary conditions, forcing etc.) and for model evaluation.

Closely connected with hindcast and forecast, and missing in our review is a discussion of models that assimilate observational data, either from satellite or in situ. Most of these models (for the Gulf of Mexico) have not been thoroughly documented, and have not been adequately tested against (independent) observations. Our own work appears in Oey [2004b] and Oey et al. [2005], as well as in Wang et al., [2003] and Fan et al., [2004], where some specific results for the DeSoto Canyon and the northeastern Gulf shelf/slope and Loop Current can be found. Our model uses simple OI [e.g., Daley, 1991] to assimilate satellite SSH anomaly [Mellor and Ezer, 1991; Ezer and Mellor, 1994] as do also many existing models, and nudging to assimilate drifters. Oey et al. [2005] use a surface-subsurface correlation that is a function of SSH anomaly; they show a forecast skill of 3 4 weeks in tracking Loop Current and Loop Current eddy frontal positions. The major source of error was found to be the initial field, and this was true for all the models tested for the same test-forecast period (August/1999-August/2000) ${ }^{20}$ Toner et al. [2001, 2003] used CUPOM, which is described in detail by Kantha et $a l$. [this volume]. Chassignet et al. [this volume] discuss data assimilation using NLOM, HYCOM and NCOM. Many hindcast and forecast models are also posted on the web. A most impressive one is http://www7320.nrlssc.navy.mil/IASNFS_ WWW/ by Ko, Preller and Martin at NRL. (Their model uses NCOM at one-twenty-fouth degree resolution and 41 sigma/zlevels.) More sophisticated assimilation techniques, such as 3DVAR and especially 4DVAR with adjoint equations should be tested in future applications. Bennett's [2002] and Kalnay's [2003] books, coupled with Daley's [1991], are excellent for

\footnotetext{
${ }^{20}$ In addition to ours, other models are CUPOM, HYCOM, NCOM and PDOM. Please see Appendix 1 subsection D for the acronyms.
} 
anyone planning to do serious work with data assimilation techniques. The adjoint-equations technique [LeDimet and Talagrand, 1986; Thacker and Long, 1988] is a particularly powerful method, not only for hindcast and forecast, but also for model initial conditions, forcing and parametric sensitivity tests; these tests in turn can provide valuable insights into physical processes and dynamics.

Acknowledgments. Gail Haller's help in acquiring copies of many of the references is greatly appreciated. Mia Shargel elevates our English to a level we do not deserve; remaining errors (for certain) are ours. We thank colleagues for reprints that they have sent us. The reviewers gave many excellent suggestions. This work is supported by the Minerals Management Service. LYO and TE also received partial supports from the Office of Naval Research.

\section{APPENDIX 1: USEFUL WEBSITES FOR DATA, MODELS AND RESEARCH}

Though most of the websites listed below are not referenced in our review, we have found them useful in our research.

\section{A. Satellite SSH and SST data:}

1. AVHRR, Gulf of Mexico Region, Ocean Remote Sensing, APL (http://fermi.jhuapl.edu/avhrr/gm/averages/index. html)

2. AVISO Altimeter Data, France (http://www.jason.oceanobs.com/html/portail/general/welcome_uk.php3)

3. CoastWatch Caribbean Region, NOAA (http://www.aoml. noaa.gov/phod/dataphod/work/trinanes/INTERFACE/ index.html)

4. CU Gulf of Mexico near real-time Altimeter Viewer, University of Colorado (http://www-ccar.colorado.edu/ $\sim$ realtime/gsfc_gom-real-time_ssh/)

5. PO.DAAC Sea Surface Temperature, JPL/NASA (http:// podaac.jpl.nasa.gov/sst/)

\section{B. GOM and Caribbean Sea Models and Observing Systems:}

COOS: Coastal Ocean Observing System, NOAA (http:// www.csc.noaa.gov/coos/)

Dynalysis Gulf of Mexico Forecast System, Dynalysis of Princeton (http://www.dynalysis.com)

IASNFS: Intra-Americas Sea Ocean Nowcast/Forecast System, NRL (http://www7320.nrlssc.navy.mil/IASNFS_ WWW/)

PROFS: Princeton Regional Ocean Forecast System (http:// www.aos.princeton.edu/WWWPUBLIC/PROFS)
Tampa Bay PORTS: Physical Oceanography Real-Time System, USF (http://ompl.marine.usf.edu/ports/)

TCOON: Texas Coastal Ocean Observation Network, TAMU (http://dnr.cbi.tamucc.edu/TCOON/)

\section{GOM Research Programs and Various Agencies:}

EPA Gulf of Mexico Program (http://www.epa.gov/gmpo/)

GMF: Gulf of Mexico Foundation (http://www.gulfofmexicofoundation.com/)

International Intra-Americas Sea Initiative (http://www. iasinitiative.org/)

MMS Gulf of Mexico Region (http://www.gomr.mms. gov/)

USGS Gulf of Mexico Integrated Science (http://gulfsci. usgs.gov/)

\section{Ocean Models:}

CANDIE: Canadian version of DieCAST (http://www.phys. ocean.dal.ca/programs/CANDIE/)

CUPOM: Colorado University version of the POM (http:// e450.colorado.edu)

DieCAST: Dietrich (Center for Air-Sea Technology) Ocean Model (http://www.ssc.erc.msstate.edu/DieCAST/)

ECOM-SI: Estuarine, Coastal and Ocean Model (SemiImplicit version) (http://woodshole.er.usgs.gov/operations/modeling/ecomsi.html)

ECOM-3D: Estuarine, Coastal and Ocean Model (3D finite difference version) (http://www.hydroqual.com/ehst_ env_hyd.html)

ECOM-SED: Estuarine, Coastal and Ocean Model (Sediment Transport version) (http://www.hydroqual.com/ehst_ ecomsed.html)

FLAME: Family of Linked Atlantic Model Experiments (http://www.ifm.uni-kiel.de/fb/fb1/tm/research/ FLAME/)

FVCOM: Finite Volume Community Ocean Model (http:// codfish.smast.umassd.edu/research_projects/FVCOM/)

HYCOM: Hybrid Coordinate Ocean Model (http://oceanmodeling.rsmas.miami.edu/hycom/)

MERCATOR: French Ocean System (http://www.mersea. eu.org $/ \mathrm{html} / \mathrm{strand} 1 /$ model $/$ mercator_overview.html)

MICOM: Miami Isopicnic Coordinates Ocean Model (http:// oceanmodeling.rsmas.miami.edu/micom/)

MITgcm: MIT General Circulation Model (http://mitgem. org/)

MOM: GFDL Modular Ocean Model (http://www.gfdl.noaa. gov/ fms)

NCOM: Navy Coastal Ocean Model (http://www7320.nrlssc. navy.mil/global_ncom/) 
NLOM: Navy Layered Ocean Model (http://www7320. nrlssc.navy.mil/global_nlom/)

OPA: Ocean Parallellise General Circulation Model (http:// www.lodyc.jussieu.fr/opa/)

PDOM: Princeton Dynalysis Ocean Model (http://www. dynalysis.com)

POM: Princeton Ocean Model (http://www.aos.princeton. edu/WWWPUBLIC/htdocs.pom/)

POP: Parallel Ocean Program (http://climate.lanl.gov/ Models/POP/)

ROMS: Regional Ocean Modeling System (http://marine. rutgers.edu/po/)

SOMS: Sandia Ocean Modeling System (earlier version of DieCAST)

\section{E. Atmospheric Models:}

COAMPS: Coupled Ocean Atmosphere Prediction System (http://www.nrlmry.navy.mil/ coamps/coamps/)

ECMWF: European Center for Medium-range Weather Forecasts (http://www.ecmwf.int/)

NCEP-ETA: National Centers for Environmental Prediction (ETA model) (http://www.nco.ncep.noaa.gov/pmb/ nwprod/analysis/)

NOGAPS: Navy Operational Global Atmospheric Prediction System (https://www.fnmoc.navy.mil/PUBLIC/)

\section{APPENDIX 2: ACRONYMS:}

ADCP: Acoustic Doppler Current Profiler

AVHRR: Advanced Very High Resolution Radiometry

AXBT: Airborne Expendable Bathythermograph

AXCP: Aircraft Expendable conductivity, temperature, depth Profiler

COADS: Comprehensive Ocean-Atmosphere Data Set

EOF: Empirical Orthogonal Functions

DAMEE: Data Assimilation and Model Evaluation Experiments

DYNAMO: Dynamics of North Atlantic Models

GCM: General Circulation Model

GDEM: Generalized Digital Environmental Model

GEK: Geomagnetic-Electro-Kinematograph

GOM: Gulf of Mexico

HT: Hurlburt and Thompson (1980)

JEBAR: Joint Effect of BAroclinicity and bottom Relief

LATEX: Louisiana-Texas shelf physical oceanography program

LCE: Loop Current Eddy

MMS: Minerals Management Service

NEGOM: North-Eastern Gulf of Mexico

NRL: Navy Research Laboratory
OI: Optimal Interpolation

PALACE floats: Profiling Autonomous LAgrangian

Circulation Explorers

PN: Pichevin and Nof (1997)

RG: Reduced Gravity model

SSH: Sea Surface Height

SST: Sea Surface Temperature

Sv: Traditional oceanographic unit of transport, $1 \mathrm{~Sv}=10^{6}$ $\mathrm{m}^{3} \mathrm{~s}^{-1}$

TRW: Topographic Rossby Waves

USF: University of South Florida

VFA: Vorticity Flux Anomaly

YC: Yucatan Channel

\section{REFERENCES}

Abascal, A. J., J. Scheinbaum, J. Candela, J. Ochoa., and A., Badan, 2003. Analysis of flow variability in the Yucatan Channel. J. Geophys. Res., 108(C12), 3381, doi:10.1029/2003JC001992.

Arango, H. G. and R. O. Reid, 1991. A generalized reduced-gravity ocean model. Atmos. Ocean, 29, 256-287.

Bennett, A. F., 2002: "Inverse Modeling of the Ocean and Atmosphere." Cambridge University Press, New York, 234 pp.

Biggs, D. C. and F. E. Muller-Karger, 1994. Ship and satellite observations of chlorophyll stocks in interacting cyclone-anticyclone pairs in the western Gulf of Mexico. J. Geophys. Res., 99, 7371-7384.

Biggs, D. C., G. S. Fargion, P. Hamilton, and R.R. Leben, 1996. Cleavage of a Gulf of Mexico Loop Current Eddy by a deep water cyclone, J. Geophys. Res., 101: 20629-20642.

Blumberg, A. F. and Mellor, G. L., 1985. A simulation of the circulation in the Gulf of Mexico. Israel J. Earth Sci., 34: 122-144.

Boicourt, W. C., W. J. Wiseman, Jr., A. Valle Levinson and L. P. Atkinson, 1998. Continental shelf of the southeastern United States and the Gulf of Mexico: In the shadow of the Western Boundary Current. In: The Sea, Vol. 11, A. R. Robinson and K. H. Brink (eds), John Wiley, NY, pp.135-182.

Bretherton, C. S., C. Smith, and J. M. Wallace, 1992: An intercomparison of methods for finding coupled patterns in climate data. J. Climate, 5 , 541-560.

Brooks, D. A., 1984. Current and hydrographic variability in the northwestern Gulf of Mexico. J. Geophys. Res., 89, 8022-8032.

Brooks, D. A. and R. V. Legeckis, 1982. A ship and satellite view of hydrographic features in the Gulf of Mexico. J. Geophys. Res., 87, 4195-4206.

Bryan, K., 1963. A numerical method for the study of the circulation of the World Ocean. J. Comput. Phys., 4, 347-376.

Bryan, K. and M. D. Cox, 1967. A numerical investigation of the oceanic general circulation. Tellus, $19,54-80$.

Bryan, F. O., C. W. Boning and W. R. Holland, 1995. On the midlatitude circulation in a high-resolution model of the North Atlantic. J. Phys. Oceanogr., 25, 289-305.

Bunge, L., J. Ochoa, A. Badan, J. Candela and J. Sheinbaum, 2002. Deep flows in the Yucatan Channel and their relation to changes in the Loop Current extension, J. Geophys. Res, 107(C12), 3233, doi:10.1029/ 2001JC001256

Candela., J., J. Scheinbaum, J. Ochoa, and A. Badan, 2002. The potential vorticity flux through the Yucatan Channel and the Loop Current in the Gulf of Mexico. Geophys. Res. Lett., 29 (22), 2059,doi:10.1029/ 2002 GL 015587.

Candela, J., S. Tanahara, M. Crepon, B. Barnier and J. Sheinbaum, 2003. Yucatan Channel flow: observations versus Clipper At16 and Mercator Pam models. J. Geophys. Res., 108 (C12), 3385, doi:10.1029/ 2003JC001961. 
Capurro, L. R. A. and J. L. Reid (Eds.), 1972. Contributions on the Physical Oceanography of the Gulf of Mexico, Texas A \& M University Oceanographic Studies, 288 pp.

Carder, K. L., K. A. Fanning, P. R. Betzer and V. Maynard, 1977. Dissolved silica and the circulation in the Yucatan Strait and the deep eastern Gulf of Mexico. Deep-Sea Res., 24, 1149-1160.

Carton, J. A. and Y. Chao, 1999. Caribbean Sea eddies inferred from TOPEX/POSEIDON altimetry and a 1/6 degrees Atlantic Ocean model simulation, J. Geophys. Res., 104 (C4): 7743-7752.

Chapman, David C., Dong S. Ko, Ruth H. Preller, 2004: A High-Resolution Numerical Modeling Study of Subtidal Circulation in the Northern South China Sea, IEEE Journal of Oceanic Engineering, 29(4). 1087-1104.

Chassignet, E. P., Arango, H., Dietrich, D., Ezer, T., Ghil, M., Haidvogel, D. B., Ma, C.-C., Mehra, A., Paiva, A. F., and Sirkes, Z., 2000. DAMEENAB: the base experiments. Dynamics of Atmospheres and Oceans 32, 155-183.

Chelton, D. B., R. A. DESzoeke, M. G. Schlax, K. E. Naggar, and N Siwertz, 1998: Geographical variability of the first baroclinic Rossby radius of deformation. J. Phys. Oceanogr., 28, 433-460.

Chen, C., R. O. Reid and W. D. Nowlin Jr., 1996: Near-inertial oscillations over the Texas-Louisiana shelf. J. Geophys. Res., 101, 3509-3524.

Cherubin, L. M., W. Sturges, and E. Chassignet. 2005. Deep flow variability in the vicinity of the Yucatan Straits from a high resolution MICOM simulation. J. Geophys Res., 110, C4: doi:10.1029/2004JC002280.

Cho, K., R. O. Reid and W. D. Nowlin, Jr., 1998. Objectively mapped stream function fields on the Texas-Louisiana shelf based on 32 months of moored current meter data. J. Geophys. Res., 103, 10,377-10,390.

Cochrane, J. D., 1972: Separation of an anticyclone and subsequent developments in the Loop Current (1969). Texas A \& M Univ. Ocean Studies. Eds: L. R. A. Capurro and J. L. Reid, Gulf Publishing Co., Houston, $2,91-106$

Cooper, C., G. Z. Forristall and T. M. Joyce, 1990. Velocity and hydrographic structure of two Gulf of Mexico warm-core rings. J. Geophys. Res., 95, 1663-1679.

Cox, M. D., 1985: An eddy resolving numerical model of the ventilated thermocline. J. Phys. Oceanogr., 15, 1312-1324.

Cushman-Roisin, B., E. P. Chassignet, and B. Tang,, 1990. Westward motion of mesoscale eddies. J. Phys. Oceanogr., 20, 758-768.

Daley, R., 1991: “Atmospheric Data Analysis," Cambridge University Press, 455 pp., NY

DeHaan, C.J. and W. Sturges, 2005. Deep cyclonic circulation in the Gulf of Mexico. J. Phys. Oceangr. In press.

Dengg, J., C. Boening, U. Ernst, R. Redler and A. Beckmann, 1999. Effects of an improved model representation of overflow water on the subpolar North Atlantic. International WOCE Newsletter, 37, WOCE International Project Office, Southampton, UK, 10-15.

Dietrich, D. E., 1993: On modeling geophysical flows having low Rossby numbers. Atmos-Ocean, 31, 57-71.

Dietrich, D. E. and C. A. Lin, 1994. Numerical studies of eddy shedding in the Gulf of Mexico. J. Geophys. Res., 99, 7599-7615.

Dietrich, D. E., C. A. Lin, A. Mestas-Nunez and D. D. Ko, 1997. A high resolution numerical study of Gulf of Mexico fronts and eddies. Meterol. Atmos. Phys., 64, 187-201.

DiMarco, S. F., M. K. Howard \& R. O. Reid, 2000: Seasonal variation of the wind-driven diurnal current on the Texas-Louisiana shelf, Geophys. Res. Lett., 27, 1017-1020.

Ducet, N., P. Y. Le Tron, and G. Reverdin, 2000. Global high-resolution mapping of ocean circulation from TOPEX/Poseidon and ERS-1\&2. J. Geophys. Res., 105, 19,477-19,498.

Elliott, B. A., 1982. Anti-cyclonic rings in the Gulf of Mexico. J. Phys. Oceanogr., 12, 1292-1309.

Ezer, T. and Mellor, G. L., 1994. Continuous assimilation of Geosat altimeter data into a three-dimensional primitive equation Gulf Stream model. J. Phys. Oceanogr., 24(4): 832-847.

Ezer, T., L.-Y. Oey, W. Sturges and H.-C. Lee, 2003. The variability of currents in the Yucatan Channel: analysis of results from a numerical ocean model, J. Geophys. Res. 10.1029/2002JC001509.
Fan, S. J., L.-Y. Oey, and P. Hamilton, 2004. Assimilation of drifters and satellite data in a circulation model of the northeastern Gulf of Mexico. Cont. Shelf Res., 24(9): 1001-1013.

Flierl, G. R., 1988. On The Instability of Geostrophic Vortices, J. Fluid Mech. 197: 349-388.

Forristal, G. Z., K. J. Schaudt, and C. K. Cooper, 1992. Evolution and kinematics of a Loop Current eddy in the Gulf of Mexico during 1985. J. Geophys. Res., 97: 2173-2184.

Fratantoni, D. M., 2001. North Atlantic surface circulation during the 1990's observed with satellite-tracked drifters. J. Geophys. Res., 106, 22,067-22,093.

Fratantoni, P. S., T. N. Lee, G. P. Podesta, and F. Muller-Karger, 1998. The influence of Loop Current perturbations on the formation and evolution of Tortugas eddies in the southern Strait of Florida. J. Geophys. Res., 103, 24,759-24,799.

Frolov, S. A., G. G. Sutyrin, G. D. Rowe and L. M. Rothstein, 2004. Loop Current eddy interaction with the western boundary in the Gulf of Mexico. J. Phys. Oceanogr., 34, 2223-2237.

Gordon, A. L., 1967. Circulation of the Caribbean Sea. J. Geophys. Res., $72,6207-6223$.

Greatbatch, R. J. and G. L. Mellor, 1999: An overview of coastal ocean models. In: Mooers, C. N. K. (Ed.), Coastal Ocean Prediction, American Geophysical Union, Washington, DC, pp. 31-57.

Griffies, S. M., C. Böning, F. O. Bryan, E. P. Chassignet, R. Gerdes, H. Hasumi, A. Hirst, A. M. Treguier and D. Webb, 2000. Developments in ocean climate modelling. Ocean Modelling, 2, 123-192.

Grimshaw, R., D. Broutman, X. He, and P. Sun, 1994: Analytical and numerical study of a barotropic eddy on a topographic slope. J. Phys. Oceanogr., 24, 1587-1607.

Gutierrez de Velasco, G. and C. D. Winant, 1996. Seasonal patterns of a wind stress curl over the Gulf of Mexico. J. Geophys. Res., 101, $18,127-18,140$.

Hamilton, P. 1990. Deep currents in the Gulf of Mexico. J. Phys. Oceanogr., 20: 1087-1104.

Hamilton, P., 1992. Lower Continental Slope Cyclonic Eddies in the Central Gulf of Mexico. J. Geophys. Res., 97: 2185-2200.

Hamilton, P., T. J. Berger, J. H. Churchill, R. R. Leben, T. N. Lee, J. J. Singer, W. Sturges and E. Waddell, 2000. Desoto Canyon eddy intrusion study. Final Report. OSC Study, MMS 2000-080, Vol. II: Tech. Rep. U.S. Dept. of the Interior, Mineral Management Service, New Orleans, LA, 269 pp.

Hamilton, P., and A. Lugo-Fernandez, 2001. Observations of high speed deep currents in the northern Gulf of Mexico. Geophys. Res. Lett., 28, 2867-2870.

Hamilton, P., T. J. Berger, and W. Johnson, 2002. On the structure and motions of cyclones in the northern Gulf of Mexico. J. Geophys. Res. 107,3208 doi:10.1029, 1-18.

Hamilton, P., K. Donahue, J. J. Singer, E. Waddell, and, 2003. Desoto Canyon extention study. Final Report. OSC Study, MMS 2003, Vol. II: Tech. Rep. U.S. Dept. of the Interior, Mineral Management Service, New Orleans, LA, 95 pp.

Hetland, R. D., Y. Hsueh, R. R. Leben and P. P. Niiler, 1999. A loop current - induced jet along the edge of the west Florida shelf. Geophys. Res. Letters, 26, 2239-2242.

Heburn, G. W., T. H. Kinder, J. H. Allender, and H. E. Hurlburt, 1982. A numerical model of eddy generation in the southeastern Caribbean Sea. In Hydrodynamics of Semi-Enclosed Seas, edited by J. C. J. Nihoul, pp.299-328, Elsevier Sci., New York.

Hofmann, E. E. and S. J. Worley, 1986. An investigation of the circulation of the Gulf of Mexico. J. Geophys. Res., 91, 14,221-14,238.

Huh, O. K., W. J. Wiseman, Jr. and L. J. Rouse, Jr., 1981. Intrusion of loop current waters onto the west Florida continental shelf. J. Geophys. Res., 86, 4186-4192.

Hurlburt, H. E., 1986: Dynamic transfer of simulated altimeter data into subsurface information by a numerical ocean model. J. Geophys. Res., 91, 2372-2400.

Hurlburt, H. E., and J. D. Thompson, 1980. A numerical study of Loop Current intrusions and eddy shedding. J. Phys. Oceanogr., 10, 1611-1651. 
Hurlburt, H. E. and J. D. Thompson, 1982. The dynamics of the loop current and shed eddies in a numerical model of the Gulf of Mexico. In: Hydrodynamics of Semi-enclosed Seas, ed. J. C. J. Nihoul, Elsevier Science, New York, NY., 243-297.

Hurlburt, H. E., A. J. Wallcraft, W. J. Schmitz Jr., P. J. Hogan, and E. J. Metzger, 1996. Dynamics of the Kuroshio/Oyashio current system using eddy-resolving models of the North Pacific Ocean. J. Geophys. Res. 101, 941-976.

Hurlburt, H. E., and P. J. Hogan, 2000. Impact of 1/8o to 1/64o resolution on Gulf Stream model-data comparison in basin-scale subtropical Atlantic Ocean models. Dyn. Atmos. Oceans, 32, 283-329.

Jochens, A. E., S. F. DiMarco, S. F. Nowlin Jr., W. D. Reid and M. C. Kennicutt, 2002. Northeastern Gulf of Mexico chemical oceanography and hydrography study: Synthesis report. Tech. Rep., OCS Study MMS 2002-055, U.S. Dept. of the Interior, Mineral Management Service, New Orleans, $586 \mathrm{pp}$

Johns, W. E., T. L. Townsend, D. M. Fratantoni and W. D. Wilson, 2002. On the Atlantic inflow to the Caribbean Sea. Deep Sea Res. 49, 211-243.

Kalnay, E, 2003: "Atmospheric modeling, data assimilation and predictability.” Cambridge University Press, New York, 341 pp.

Ko, Dong S., Ruth H. Preller, and Paul J. Martin, 2003a: An Experimental Real-Time Intra Americas Sea Ocean Nowcast/Forecast System for Coastal Prediction, Proceedings, AMS 5th Conference on Coastal Atmospheric \& Oceanic Prediction \& Processes.

Ko, D. S, R. H. Preller, G. A. Jacobs, T. Y. Tang, and S. F. Lin, 2003b: Transport Reversals at Taiwan Strait during October and Novemeber 1999. J. Geophys. Res., 108 (C11), 34-1 to 34-13, doi: 10.1029/2003JC001836.

LaCasce, J. H., 1998. A geostrophic vortex over a slope. J. Phys. Oceanogr. 28, 2362-2381.

LeDimet,F. X. and O. Talagrand, 1986: Variational algorithms for analysis and assimilation of meteorological observations: Theoretical aspects. Tellus, 38A, 97-110.

Lee, H. C., and G. L. Mellor, 2003. Numerical simulation of the Gulf Stream System: The Loop Current and the deep circulation. J. Geophys. Res., 108(C2), 3043,doi: 10.1020/2001CJ001074.

Leipper, D. F., 1970. A sequence of current patterns in the Gulf of Mexico. J. Geophys. Res., 75, 637-657.

Lewis, J. K. and A. D. Kirwan, Jr., 1987. Genesis of a Gulf of Mexico ring as determined from kinematic analyses. J. Geophys. Res., 92, $11,727-11,740$

Li, Y., W. D. Nowlin, Jr. and R. O. Reid, 1997. Mean hydrographic fields and their interannual variability over the Texas-Louisiana continental shelf in spring, summer and fall. J. Geophys. Res., 102, 1027-1049.

Marshall, J., C. Hill, L. Perelman, and A. Adcroft, 1997: Hydrostatic, quasi-hydrostatic, and nonhydrostatic ocean modeling. J. Geophys. Res., Oceans, 102 (C3), 5733-5752.

Meincke, J., Le Provst, C., Willebrand, J., 2001. Dynamics of the North Atlantic circulation (DYNAMO). Progress in Oceanography 48, 2-3.

Merrell, W. J., Jr. and J. M. Morrison, 1981. On the circulation of the western Gulf of Mexico with observations from April 1978. J. Geophys. Res., 86, 4181-4185.

Martin, P. J., 2000. Description of the Navy Coastal Ocean Model. Report NRL/FR/7322-00-9962, Naval Res. Lab. SSC, Ms 39529-5004

Matsuura, T. and T. Yamagata, 1982. On the evolution of nonlinear planetary eddies larger than the radius of deformation. J. Phys. Oceanogr., $12,440-456$

Maul, G. A, 1977. The annual cycle of the Gulf Loop Current. Part I: Observations during a one-year time series, J. Mar. Res., 35, 29-47.

Maul, G. A., D. A. Mayer and S. R. Baig, 1985. Comparisons between a continuous 3-year current-meter observation at the sill of the Yucatan Strait, satellite measurements of Gulf Loop Current area, and regional sea level, J. Geophys. Res.,90, 9089-9096.

Mellor, G. L. and Ezer, T., 1991. A Gulf Stream model and an altimetry assimilation scheme. J. Geophys. Res, 96: 8779-8795.

Mellor, G. L., and T. Yamada, 1982. Development of a turbulence closure model for geophysical fluid problems, Rev. Geophys. Space Phys., 20, $851-875$.
Mizuta, G. and N. G. Hogg, 2004: Structure of the circulation induced by a shoaling topographic wave. J. Phys. Oceanogr., 34, 1793-1810.

Morey, S. L., P. J. Martin, J. J. O'Brien, A. A. Wallcraft, and J. ZavalaHidalgo, 2003. Export pathways for river discharged fresh water in the northern Gulf of Mexico. J. Geophys Res., 108(C10), 3303,doi: 10.1029/2002JCOO1764.

Molinari, R. L., 1977: The annual cycle of the Gulf Loop Current. Part I: observations during a one-year time series. J. Mar. Res., 35, 29-47.

Molinari, R. L. and J. Morrison, 1988. The separation of the Yucatan Current from the Campeche Bank and the intrusion of the loop current into the Gulf of Mexico. J. Geophys. Res., 93, 10,645-10,654.

Mooers, C. N. K. and G. A. Maul, 1998. Intra-Americas Sea Circulation. In: The Sea, Vol. 11, K. H. Brink and A. R. Robinson (eds), John Wiley, NY, pp.183-208.

Muller-Karger, F.E., 2000: The spring 1998 northeastern Gulf of Mexico (NEGOM) cold water event: remote sensing evidence for upwelling and for eastward advection of Mississippi water. Gulf of Mexico Science, 2000(1), 55-67.

Murphy, S. J., H. E. Hurlburt and J. J. O’Brien, 1999. The connectivity of eddy variability in the Caribbean Sea, the Gulf of Mexico, and the Atlantic Ocean. J. Geophy. Res., 104, 1431-1453.

Nof, D., 1999: Strange encounters of eddies with walls. J. Mar. Res., 57, 739-761.

Nof, D. and T. Pichevin, 2001. The ballooning of outflows. J. Phys. Oceanogr., 31, 3045-3058.

Nof, D., S. Van Gorder and T. Pichevin, 2004. A different outflow length scale?. J. Phys. Oceanogr., 34(4), 793-804.

Nowlin, W.D., Jr., 1972. Winter circulation pattern and property distributions. Contributions on the Physical Oceanography of the Gulf of Mexico, Vol. II, L.R.A. Capurro and J.L. Reid, Eds., Gulf Publishing Co., 3-64.

Ochoa, J., J. Sheinbaum, A. Baden, J. Candela and D. Wilson, 2001. Geostrophy via Potential vorticity inversion in the Yucatan Channel, J. Mar. Res., 59, 725-747.

Oey, L.-Y., 1995. Eddy- and wind-forced shelf circulation, J. Geophys. Res., 100: 8621-8637.

Oey, L-Y., 1996. Simulation of mesoscale variability in the Gulf of Mexico, J. Phys. Oceanogr., 26, 145-175.

Oey, L-Y. 1998. Eddy energetics in the Faroe-Shetland Channel, Cont. Shelf Res., 17: 1929-1944

Oey, L.-Y., 2004a. Vorticity Flux in the Yucatan Channel and Loop Current Eddy shedding in the Gulf of Mexico. J. Geophys. Res. 109, C10004, doi:10.1029/2004JC002400.

Oey, L.-Y., 2004b: A Circulation Model of the Gulf of Mexico and the Caribbean Sea, Part I: Development of the Princeton Regional Ocean Forecast (\& Hindcast) System - PROFS, and Hindcast Experiment for 1992-1999. Draft Final Report to U.S. DOI Minerals Management Service, Herndon, Virginia, Contract\# 1435-01-00-CT-31076, by Princeton University, AOS Program, Sayre Hall, Princeton, NJ 08544 Dec/2003.

Oey, L.-Y. \& P. Chen, 1992: Simulation of circulation in NE-Atlantic shelves \& seas, J. Geophys. Res, 97: 20,087-20,115.

Oey, L.-Y. and H.-C. Lee, 2002. Deep eddy energy and topographic Rossby waves in the Gulf of Mexico, J. Phys. Oceanogr., 32: 3499-3527.

Oey, L.-Y., H.-C. Lee and W. J. Schmitz Jr., 2003. Effects of Winds and Caribbean Eddies on the Frequency of Loop Current Eddy Shedding: A Numerical Model Study, J. Geophys. Res., 108 (C10), 3324, doi:10.1029/ 2002JC001698, 2003.

Oey, L.-Y. and H.-C. Zhang, 2004. A mechanism for the generation of subsurface cyclones and jets. Cont. Shelf Res., 24, 2109-2131.

Oey, L.-Y., T. Ezer \& T. Sturges, 2004. Modeled and Observed Empirical Orthogonal Functions of Currents in the Yucatan Channel. J. Geophys. Res., 109, C08011, 10.1029/2004JC002345.

Oey L.-Y., T. Ezer, G. Forristall, C. Cooper, S. DiMarco, S. Fan, 2005: An exercise in forecasting loop current and eddy frontal positions in the Gulf of Mexico, Geophys. Res. Lett., 32, L12611, doi:10.1029/ 2005 GL023253. 
Ohlmann, J. C., P. P. Niiler, C. A. Fox and R. R. Leben, 2001. Eddy energy and shelf interactions in the Gulf of Mexico. J. Geophys. Res., 106, 2605-2620

Paluszkiewicz, T., L.P. Atkinson, E.S. Posmentier and C.R. McClain, 1983. Observation of a Loop Current frontal eddy intrusion onto the west Florida shelf. J. Geophys. Res., 9639-9651.

Paskausky, D. F. and R. O. Reid, 1972. A barotropic prognostic numerical circulation model. In: Contributions on the Physical Oceanography of the Gulf of Mexico. Texas A \& M Univ. Ocean. Studies, ed. L. R. A. Capurro and J. L. Reid, Gulf Publishing Co., Houston, 163-176.

Pillsbury, J.E., 1887: Gulf Stream explorations-observations of currents, Appendix 8, Report Supt. U.S. Coast and Geodetic Survey, 281-290.

Pichevin, T., and D. Nof, 1997. The momentum imbalance paradox. Tellus, 49A, 298-319.

Reid, R.O., 1972. A simple dynamic model of the Loop Current. Contributions on the Physical Oceanography of the Gulf of Mexico, Vol. II, L.R.A. Capurro and J.L. Reid, Eds., Gulf Publishing Co., 157-159.

Reid, R. O. and O. Wang, 2004. Bottom-trapped Rossby waves in an Exponentially stratified ocean. J. Phys. Oceanogr., 34(4), 961-967.

Richardson, P. L., 2005. Caribbean Current and eddies as observed by surface drifters. Deep Sea Res., II, 52, 429-463.

Romanou, A., E. P. Chassignet, and W. Sturges, 2004. The Gulf of Mexico circulation within a high resolution numerical simulation of the North Atlantic Ocean.. J. Geophys. Res., 109, CO1003, doi: 10.1029/2003CJ001770.

Sarmiento, J. L. and Bryan, K., 1982. An ocean transport model for the North Atlantic. J. Geophys. Res., 87: 394-408.

Schlitz, R. J., 1973: Net total transport and net transport by water mass categories for Yucatan Channel, based on data for April, 1970. PhD. Dissertation, Texas A \& M Univ., 107pp.

Schmitz, W. J., Jr., 1996. On the World Ocean Circulation: Volume I-Some Global Features/North Atlantic Circulation. WHOI Technical Report WHOI-96-03, $141 \mathrm{pp}$.

Semtner, A. J., Jr. and R. M. Chervin, 1992. Ocean general circulation from a global eddy-resolving model. J. Geophys. Res., 97, 5493-5550.

Shay, L. K., A. J. Mariano, S.D. Jacob \& E.H. Ryan, 1998: Mean and nearinertial ocean current response to hurricane Gilbert. J. Phys. Oceanogr., 28: $858-889$.

Sheinbaum, J., J. Candela, A. Badan and J. Ochoa, 2002. Flow structure and transports in the Yucatan Channel, Geophys. Res. Let., 29(3), 10.1029/2001GL0139990.

Sheng, J., R. J. Greatbatch, and D. G. Wright, 2001. Improving the utility of ocean circulation models through adjustment of the momentum balance. J. Geophys. Res., 106, 16,711-16,728.

Sheng, J. and L. Tang, 2003. A Numerical study of circulation in the western Caribbean Sea. J. Phys. Oceanogr., 33, 2049-2069.

Sheng, J. and L. Tang, 2004. A two-way nested-grid ocean circulation model for the Meso-American Barrier Reef System. Ocean Dynamics, $54,232-242$.

Shi, C. and D. Nof, 1993. The splitting of eddies along boundaries. J. Mar. Res., 51, 771-795.

Simmons, H. L. and D. Nof, 2002. The squeezing of eddies through gaps. J. Phys. Oceanogr., 32, 314-335.

Simpson, J. H., P. Hyder and T. P. Rippeth, 2002: Forced oscillations near the critical latitude for diurnal-inertial resonance. J. Phys. Oceanogr., 32: $177-187$.

Stockwell, R. G., W. G. Large and R. F. Milliff, 2004: Resonant inertial oscillations in moored buoy ocean surface winds. Tellus, 56A, 536-547.

Smagorinsky, J., 1963: General circulation experiments with the primitive equations. Part I: the basic experiment. Mon. Wea. Rev., 91, 99-164.

Smith, D. C., IV and R. O. Reid, 1982. A numerical study of nonfrictional decay of mesoscale eddies. J. Phys. Oceanogr., 12, 244-255.

Smith, D. C., IV and J. J. O'Brien, 1983. The interaction of a two-layer isolated mesoscale eddy with topography. J. Phys. Oceanogr., 13, 1681-1697.
Smith, D. C., IV, 1986. A numerical study of loop current eddy interaction with topography in the western Gulf of Mexico. J. Phys. Oceanogr., $16,1260-1272$

Smith, D. C., IV and A. A. Bird, 1989. Factors influencing asymmetry and self advection in ocean eddies. In: Mesoscale/Synoptic Coherent Structures in Geophysical Turbulence, eds. J. C. J. Nihoul and B. M. Jamart, Elsievier Science Publishers, Amsterdam, 211-224.

Smith, R. D., M. E. Maltrud, F. O. Bryan and M. W. Hecht, 2000. Numerical simulation of the North Atlantic Ocean at 1/10 deg. J. Phys. Oceanogr., 30, 1532-1561.

Smith, S. R. and G. A. Jacobs, 2005. Seasonal circulation fields in the northern Gulf of Mexico calculated by assimilating current meter, shipboard ADCP, and drifter data simultaneously with the shallow water equations. Cont. Shelf Res., 25, 157-183.

Sturges, W., 1992. The spectrum of loop current variability from gappy data. J. Phys. Oceanogr., 22, 1245-1256.

Sturges, W., 1993. The annual cycle of the western boundary current in the Gulf of Mexico. J. Geophys. Res., 98, 18,053-18,068.

Sturges, W., J. C. Evans, W. Holland and S. Welsh, 1993. Separation of warm-core rings in the Gulf of Mexico, J. Phys. Oceanogr., 23, $250-268$

Sturges, W. and R. Leben, 2000. Frequency of ring separations from the Loop Current In the Gulf of Mexico: A revised estimate, J. Phys. Oceanogr., 30, 1814-1818.

Sutyrin, G., D. Rowe, L. Rothstein and I. Ginis, 2003. Baroclinic-eddy interactions with continental slopes and shelves. J. Phys. Oceanogr., 33, 283-291.

Teague, W. J., M. J. Carron and P. J. Hogan, 1990: A comparison between the Generalized Digital Environmental Model and Levitus climatologies, J. Geophy. Res. 95, 7167-7183.

Thacker, W. C. and R. B. Long, 1988: Fitting dynamics to data. J. Geophys. Res. 93, 1227-1240.

Toner, M., A. D. Kirwan, L. H. Kantha, and J. K. Choi, 2001. Can general circulation models be assessed and their output enhanced with drifter data?. J. Geophys. Res., 106(C9), 19,563-19,579.

Toner, M., A. D. Kirwan Jr., A. C. Poje, L. H. Kantha, F. E. MullerKarger and C. K. R. T. Jones, 2003. Chlorophyll dispersal by eddyeddy interactions in the Gulf of Mexico. J. Geophys. Res., 108(C4) 10.1029/2002JC001499.

Tselioudis, G., W. B. Rossow, A. N. Gentilcore and J. Katzfey, 2004. The data integration for model evaluation web site. Bull. Amer. Met. Soc., 85(6), 830-835.

Vallis, G. K. and M. E. Maltrud, 1993. Generation of mean flows and jets on a beta plane and over topography. J. Phys. Oceanogr., 23, 1346-1362.

Vidal, V. M. V., F. V. Vidal and J. M. Perez-Molero, 1992. Collision of a Loop Current anticyclonic ring against the continental slope of the western Gulf of Mexico. J. Geophys. Res. 97, 2155-2172.

Vidal, V. M. V., F. V. Vidal, A, F. Hernandez, E. Meza and J. M. PerezMolero, 1994.Baroclinic flows, transports, and kinematic properties in a cyclonic-anticyclonic-cyclonic triad in the Gulf of Mexico. J. Geophys. Res., 99(C4), 7571-7598.

Vukovich, F. M., B. W. Crissman, M. Bushnell and W. J. King, 1979. Some aspects of the Gulf of Mexico using satellite and in-situ Data. J. Geophys. Res., 84, 7749-7768.

Vukovich, F. M. and G. A. Maul, 1985. Cyclonic eddies in the eastern Gulf of Mexico. J. Phys. Oceanogr. 15, 105-117.

Vukovich, F. M., 1986. Aspects of the behavior of cold perturbations in the eastern Gulf of Mexico: a case study. J. Phys. Oceanogr., 16, 175-188.

Vukovich, F. M. and B. W. Crissman, 1986. Aspects of warm rings in the Gulf of Mexico. J. Geophys. Res., 91, 2645-2660.

Vukovich, F. M., 1995. An updated evaluation of the Loop Currents eddyshedding frequency. J. Geophys. Res. 100, 8655-8659.

Wallcraft, A., 1986. Gulf of Mexico Circulation Modeling Study, Year 2. Progress Report by JAYCOR, submitted to the Minerals Management Service, Metairie, LA. Contract No. 14-12-0001-30073.

Wang, D.-P., L.-Y. Oey, T. Ezer and P. Hamilton, 2003. Nearsurface currents in DeSoto Canyon. J. Phys. Oceanogr., 33: 313-326. 
Weisberg, R. H., He, R., 2003. Local and deep-ocean forcing contributions to anomalous water properties on the West Florida Shelf. J. Geophys. Res., 108(C6), 10.1029/2002JC001407.

Welsh, S. E. and M. Inoue, 2000. Loop current rings and deep circulation in the Gulf of Mexico. J. Geophys. Res., 105, 16,951-16, 959.

Wert, R. T. and R. O. Reid, 1972. A baroclinic prognostic numerical circulation model. In: Contributions I Physical Oceanography of the Gulf of Mexico, Texas A\&M Univ., Oceanographic studies, eds. L. R. A. Capuro and J. L. Reid, Gulf Publishing Co., Houston, 177-209.

Zavala-Hidalgo, J., S. L., Morey, and J. J. O’Brien, 2003a. Cyclonic eddies northeast of the Campeche Bank from altimetry data. J. Phys. Oceanogr., $33,623-629$.
Zavala-Hidalgo, J., S. L., Morey, and J. J. O’Brien, 2003b. Seasonal circulation on the western shelf of the Gulf of Mexico using a high resolution numerical model. J. Geophys. Res., 108 (C12), 3389, doi: 10.1029/2003JCOO1879.

Zavala-Sanson, L., F. Graef, and E. G., Pavia, 1998: Collision of anticyclonic, lens-like eddies with a meridional western boundary. J. Geophys. Res. 103, 24,881-24,890.

L.-Y. Oey, T. Ezer, and H.-C. Lee, Program in Atmospheric and Oceanic Sciences, Princeton University, Princeton, New Jersey, \#GFDL, NOAA, Princeton, NJ 08540 